\title{
Regulation of CDK4
}

\section{Laurence Bockstaele, Katia Coulonval, Hugues Kooken, Sabine Paternot and Pierre P Roger*}

\author{
Address: Institute of Interdisciplinary Research (IRIBHM), Faculté de Médecine, Université Libre de Bruxelles, Campus Erasme, B-1070 Brussels, \\ Belgium \\ Email: Laurence Bockstaele - Laurence.Bockstaele@ulb.ac.be; Katia Coulonval - kcoulonv@ulb.ac.be; Hugues Kooken - hkooken@ulb.ac.be; \\ Sabine Paternot - spaterno@ulb.ac.be; Pierre P Roger* - proger@ulb.ac.be \\ * Corresponding author
}

Published: 08 November 2006

Cell Division 2006, I:25 doi:10.1 186/1747-1028-1-25

This article is available from: http://www.celldiv.com/content/I/I/25

(C) 2006 Bockstaele et al; licensee BioMed Central Ltd.

This is an Open Access article distributed under the terms of the Creative Commons Attribution License (http://creativecommons.org/licenses/by/2.0), which permits unrestricted use, distribution, and reproduction in any medium, provided the original work is properly cited.
Received: 02 November 2006

Accepted: 08 November 2006

\begin{abstract}
Cyclin-dependent kinase (CDK)4 is a master integrator that couples mitogenic and antimitogenic extracellular signals with the cell cycle. It is also crucial for many oncogenic transformation processes. In this overview, we address various molecular features of CDK4 activation that are critical but remain poorly known or debated, including the regulation of its association with D-type cyclins, its subcellular location, its activating Thr I72-phosphorylation and the roles of Cip/Kip CDK "inhibitors" in these processes. We have recently identified the T-loop phosphorylation of CDK4, but not of CDK6, as a determining target for cell cycle control by extracellular factors, indicating that CDK4-activating kinase(s) might have to be reconsidered.
\end{abstract}

\section{Background}

At least during embryonic development in mice, CDK4 and its cousin CDK6, as well as their common regulatory partners the three D-type cyclins, are not absolutely required for cell cycle progression $[1,2]$. E-type cyclins and CDK2 are similarly dispensable for embryo cell proliferation [3-6]. However, loss of CDK4 and CDK2 together (but not combined loss of CDK6 and CDK2 [1]) results in suppressed $\mathrm{pRb}$ phosphorylation at midgestation, more severe size reduction in the different organs, embryonic lethality due to heart failure and severe impairment of embryo cell proliferation in culture [7]. Previously, silencing of CDK2 was found to block proliferation in triple cyclin D knockout embryo fibroblasts but not in their wildtype counterparts [2]. This demonstrates the limits of the once unexpected plasticity of cell cycle regulation in mammalian embryo development and of the possible compensation of functions operated by both kinds of G1 phase cyclin-CDK complexes.
That does not mean that cell cycle progression in adult differentiated tissues could normally occur without CDK4 and/or CDK6. For instance CDK4 is dispensable for prenatal development of the pituitary but indispensable for postnatal proliferation of somato/lactotrophs [8]. Similarly, cyclins D2 and D1 are essential for postnatal but not prenatal pancreatic beta-cell growth [9]. Another good illustration is the appearance of the cell cycle requirement for cyclin D3 associated with the maturation of T lymphocyte [10] or late stages of neutrophil development [11]. Indeed, first cell divisions in the mammalian embryo depend on maternal transcripts and proteins, and then in most differentiating lineages cell cycle might proceed without most of the restrictions that control adult cell proliferation [12]. Many embryo cell cycles have a short G1 phase and do not pause in a G0 stage, and thus all the cell circuitry involved in the signalling of cell cycle re-entry from G0 might be partly dispensable until relatively late developmental stages. CDK1 can be activated 
by cyclin $\mathrm{E}$ and thus can compensate CDK2 loss in mice development [13], leading to the perhaps oversimplified vision of the embryonic cell cycle as a basic module resembling the yeast cell cycle that depends on only one CDK. During differentiation, different combinations of the six possible cyclin D1/2/3-CDK4/6 complexes may become adjunct to (plugged in) this core cell cycle module to couple its execution to the various intracellular cascades that transduce signals needed in the whole organism homeostasis.

During later stages of development and in adults, D-type cyclins CDK4/6 complexes thus appear to play essential, yet facilitative, roles as master integrators of the various mitogenic and antimitogenic signals conveyed by the extracellular environment. They are also regulated in response to intracellular mechanisms that sense the metabolic state of the cell, including its energetic and biosynthetic status, and respond to various stresses. According to their tissue-specific, but greatly overlapping, expression patterns, individual D-type cyclins have been shown to be required for proliferation and development of specific tissues (as reviewed in [14]), such as mammary gland and retina for cyclin D1, gonads, B-lymphocyte and pancreatic $\beta$-cells for cyclin D2, and maturation of T-lymphocytes for cyclin D3. Like cyclin D1-null mice, CDK4-null mice are smaller, but additionally display abnormalities seen in cyclin D2-deficient mice, including impaired development of pancreatic $\beta$-cells [15], whereas CDK6-null mice suffer from haematopoietic defects (reviewed in [14]). It remains somewhat unclear if these specific phenotypes depend only on the particular tissue-specific expression profiles of the various D-type cyclins and their association with CDK4 or CDK6, or might also be related to some non-overlapping functions of their different complexes. At least partial compensation between different D-type cyclins has been well demonstrated [16-18], but it has not been systematically explored in adult tissues. It has recently appeared that CDK6 cannot compensate CDK4 loss in a CDK2-null background [19], but CDK6 might have specific functions in blocking some differentiation processes [20]. Differentiation is often associated with dramatic D-type cyclins' expression switches. In several adult mammalian tissues, cyclin D1 localizes to proliferative layers, whereas cyclin D3 is often highly expressed in the adjacent compartment where differentiation takes place [21-24]. Cyclin D3 replaces cyclin D1 during myogenesis $[25,26]$, adipogenesis [27], or at the pre-TCR developmental stage during $\mathrm{T}$ lymphocyte maturation [10].

The six D-type cyclin-CDK4/6 complexes phosphorylate and inactivate the cell cycle/tumor suppressor proteins of the pRb family $\left(\mathrm{p} 105^{R b}, \mathrm{p} 107, \mathrm{p} 130^{R b 2}\right)$ [28-33]. This function is indeed essential since the CDK4/6 inhibitor p16 or neutralization of cyclin D1 do not prevent cell cycle progression in pRb-defective cells [34-36]. However, there are also some indications that CDK4/6 can phosphorylate other substrates. Recently, CDK4 (and CDK2) was demonstrated to phosphorylate and inactivate Smad3 [37]. Direct phosphorylations by CDK4 of the nucleolar transcription factor upstream binding factor (UBF) [38], the replication licensing factor Cdt1 [39], the bone-specific transcription factor Runx2 [40], and possibly TSC2 [41] have been reported. Differential phosphorylation of unidentified substrates by cyclin D1-CDK4 or cyclin D3CDK4/6 was observed [42]. Moreover, cyclin D3 complexes more efficiently phosphorylate p130 than do cyclin D1 complexes [43]. Finally, CDK4 and CDK6 may have different preferences for phosphorylation of specific sites in pRb protein [44], and we have recently found distinct specificities of $\mathrm{pRb}$ phosphorylation by CDK4 activated by cyclin D1 or cyclin D3 [45].

CDK4 activity is deregulated in many human tumors $[46,47]$. It has been recently confirmed to be crucial for various oncogenic transformation processes [2,48-53]. Deregulation does not only result from oncogenic hyperactivation of mitogenic signalling cascades ending at Dtype cyclin gene transactivation. Every particular component of "the Rb pathway" act as tumor suppressors or protooncogenes (reviewed in $[14,46,47])$. Amplification or rearrangement of the genes encoding cyclins D1, D2 and D3 have been found in many human cancers and leukaemias. Oncogenic mutations of cyclin D1 enforcing its nuclear accumulation have been recently described [54]. Loss of p16 by mutation, deletion or gene silencing is extremely frequent. CDK4 itself is overexpressed as a result of gene amplification, or subject to a mutation that renders it insensitive to p16. Interesting models of CDK4/ 6 deregulation are also provided by some oncogenic viruses. Cyclin K encoded by Kaposi's sarcoma-associated herpesvirus strongly activates CDK6 and CDK4 through original mechanisms [55], and the Tax oncoprotein of human T-cell leukaemia virus type 1 directly binds to and activate CDK4, which involves enhanced cyclin D interaction and suppression of inhibition by p16 $[56,57]$.

\section{CDK4 regulation}

The so widespread deregulation of CDK4 in cancers underscores the necessity to fully understand the various mechanisms involved in its activation process. As initially considered, mitogens activate CDK $4 / 6$ by inducing at least one D-type cyclin (D1, D2 and D3) to concentrations allowing to overcome an inhibitory threshold imposed by INK4 CDK4/6 inhibitory proteins [58]. These proteins (p15, p16, p18, p19) bind to the catalytic domain of the isolated CDK4/6, thus preventing cyclin association and activation [59-61]. In short, the synthesis of cyclin D1 and cyclin D2 is stimulated by various 
mitogenic factors and repressed by growth inhibitory treatments (though cyclin D3 is often associated with quiescent cells [21]). On the opposite, the accumulation of INK4 inhibitory proteins is increased in anti-proliferative situations, such as senescence (p16), TGF $\beta$ treatment (p15)[62] or specific differentiation processes (p18 and p19)[63]. In some systems, CDK4 expression itself is increased, which can potentially titrate INK4 proteins, explaining for instance that overexpression of CDK4 can relieve TGF $\beta$ inhibition of proliferation [64].

Increased expression of a D-type cyclin is clearly not sufficient to activate CDK4. In this overview, we will address various molecular features of CDK4 activation that are critical but remain poorly known or debated, including the regulation of its association with D-type cyclins, its subcellular location, its activating Thr172-phosphorylation and the roles of Cip/Kip CDK "inhibitors" in these processes. We will often evocate questions raised by the Sphase entry in a specific model system that we have characterized, the primary culture of canine thyroid epithelial cells $[65,66]$. Indeed, this physiologically relevant model displays several interesting features, including the coexistence of two very distinct mitogenic pathways $[67,68]$, which both require CDK4 activity $[69,70]$ : (i) a canonical mitogenic stimulation by growth factors associated with reversible dedifferentiation, and (ii) a mitogenic stimulation associated with enhanced thyroid function and differentiation expression by the physiological stimulus, TSH, which signals only through elevation of cellular cyclic AMP levels without activating most of the classical intermediates of growth factor-dependent cascades (including Ras, ERKs and PI3-kinase pathways)[65,7173]. Paradoxically, this cAMP-dependent triggering of cell cycle progression involves an accumulation of the p27kip1 CDK inhibitor [74] but not of the D-type cyclins [70], as observed in cell systems where cAMP blocks G1 phase progression $[75,76]$. Cyclin D3 is nevertheless required in this differentiation-compatible mitogenic stimulation, but not for the proliferation stimulation by growth factors that induce the other D-type cyclins [70]. This specific requirement for cyclin D3 is consistent with the emerging concept that cyclin D3 might be more specifically involved in specialized cell cycles associated with maintenance or induction of differentiation $[10,21,45]$.

\section{Regulated assembly of D-type cyclin-CDK4 complexes}

Early studies by the group of Sherr have shown that Dtype cyclins and CDK4 do not assemble spontaneously in vitro, but nevertheless can form active complexes when marinated with an extract of proliferating NIH3T3 cells, but not (as reported but not shown) with extracts of growth-factor deprived cells [77]. Since the association of CDK4 with the cyclin D was not shown in these experiments, this assay could not discriminate between assem- bly and activation activities. Nevertheless, using NIH 3T3 cells engineered to constitutively express both cyclin D3 or cyclin D1 and CDK4, the same authors showed that the formation of cyclin D1/3-CDK4 complexes depends on serum stimulation [78], which can be replaced by expression of an activated form of MEK1 [79]. However, in a similar experimental setting, Ladha et al [80] found that overexpressed cyclin D1 can efficiently assemble with endogenous CDK4 to form inactive complexes in serumdeprived NIH 3T3 cells. Cyclin D3-CDK4 complexes are also constitutively assembled in $\mathrm{G}_{0}$ cells such as serumdeprived Balb c 3T3 cells [81] and T98G cells [82].

The dog thyrocyte system has provided the first evidence for a critical regulation of D-type cyclin-CDK4 assembly by a physiological mitogenic stimulus [70]. In these cells, cyclin D3 is abundantly expressed depending in part on the presence of comitogenic factors (insulin and carbachol), whereas CDK4 is constitutively expressed. TSH and CAMP trigger the entry into S-phase at least in part by promoting the assembly of required cyclin D3-CDK4 complexes [70,83-85]. Other examples of regulation of the formation of D-type cyclin-CDK4/6 complexes unexplained by modulations of cyclin D or CDK $4 / 6$ presence were found in B lymphocytes [86], or FSH-stimulated granulosa cells of hamster preantral follicles [87].

Such findings led to the suggestion that an assembly factor might be required for the assembly of cyclin D-CDK4 complexes $[77,78]$. In recent years, several interactors of cyclins D or CDK4/ 6 have been proposed to play a role in the formation of their complex. They are discussed below:

\section{p21/p27}

At variance with initial reports (reviewed in [59]), Cip/Kip CDK inhibitors ( $\left.\mathrm{p} 21^{\text {cip } 1}, \mathrm{p} 27^{k i p} 1\right)$ have been paradoxically found to be associated with a pRb-kinase activity ascribed to CDK4 [82,88-91]. As they possess distinct binding domains for cyclins and CDKs, they were proposed as the elusive adaptors for the assembly of D-type cyclin-CDK complexes. Indeed, LaBaer and colleagues found that p21 and p27 can promote the formation of these complexes in vitro or in cotransfected cells (yet only p 21 could support the pRb-kinase activity) [90]. p21 and p27 were even concluded to be essential for this function, on the basis of the lack of detectable D-type cyclin-CDK complexes in p21/ p27-null mouse embryonic fibroblasts [92]. Nevertheless, these authors noticed that phosphorylation of $\mathrm{pRb}$ on Ser780 (a site specifically phosphorylated by CDK4/6) was unaffected. Moreover, D-type cyclin levels were also much reduced, which may in part explain the failure to detect their complexes with CDK4/6 [92]. Indeed, in similar experimental settings other authors more recently reported that p21 and p27 do stabilize cyclin D3-CDK4 [93] and cyclin D1-CDK4 [94], but are not required for 
the assembly of these active complexes, which are inhibited by p16. Moreover, Pledger's group claimed that only the minor fraction of cyclin D3-CDK4 complexes devoid of CIP/KIP proteins are active as pRb-kinases [95].

The case for $\mathrm{p} 21$ as a positive regulator of D-type cyclinCDK4 complexes is nevertheless well supported. In various cell systems, p21 is transiently induced in G1 by mitogenic factors through the Ras/Raf/ERKs cascade, which is associated with increased CDK4 activity [82,96100]. Such p21 inductions indeed appear to play a positive role in cell proliferation, as shown by silencing of $\mathrm{p} 21$ expression by antisense oligonucleotides or RNA interference [98,101-103]. However, whether the positive role of p21 is mediated by enhanced assembly of D-type cyclinCDK4 remains to be ascertained. In MCF-7 cells, p21 antisense markedly reduced cyclin D1 expression [102]. Moreover, inhibition by rapamycin of p21 expression, p21 binding to cyclin D1-CDK4 and activation of this complex were not associated with reduction of cyclin D1CDK4 assembly [104].

The TSH (cAMP)-dependent assembly of active cyclin D3CDK4 complexes in dog thyrocytes is clearly independent of p21, which is weakly expressed and repressed by TSH [100]. Instead, TSH stimulates the accumulation of p27 [74], which to our knowledge provides a unique such an example in a mitogenic stimulation. Since p27 does associate with cyclin D3-CDK4 without impairing its pRbkinase activity in TSH-stimulated cells [91], it would constitute a likely candidate as the assembly factor. However, the 2-3-fold increase of p27 levels could not plausibly explain the 10-20-fold increase of cyclin D3-CDK4 complexes induced by TSH. Moreover, inhibition by TGF $\beta$ of TSH-stimulated cyclin D3-CDK4 activity is associated with a reduction of the binding of cyclin D3 and CDK4 to p27, but not of the assembly of the cyclin D3-CDK4 complex $[85,91]$. At variance with Labaer et al [90], we were unable to detect any in vitro assembly activity of p27 for cyclin D3 and CDK4, even in conditions that allow the binding of p27 to pre-assembled cyclin D3-CDK4 complexes ([82], unpublished results). This is in agreement with previous studies showing that abundant p27 in $G_{0}$ cells is unable to assemble ectopically expressed cyclin D3 into CDK4 complexes in serum-starved fibroblasts [78].

Finally, whether the formation of D-type cyclin-CDK complexes would indeed require an assembly factor remains doubtful. The efficient assembly of strongly overexpressed ectopic cyclin D3 and CDK4 in CHO cells cannot be explained by low endogenous levels of p21 or p27 [82]. Similarly, the efficient assembly of D-type cyclins and CDK4 co-produced in insect cell by baculoviral infection is known for a long time $[77,82]$. We have been unable to detect insect cell proteins stoichiometrically associated with these very abundant complexes (Bockstaele, unpublished results), in agreement with the apparent size of $70 \mathrm{kDa}$ reported for cyclin D2-CDK4 complexes produced in insect cells [89]. However, the native active cyclin D1-CDK4 holoenzyme has been characterized as a complex with a molecular mass ranging from 150 to $200 \mathrm{kDa}[105,106]$.

Other mechanisms should thus be envisaged to explain the regulated formation of D-type cyclin-CDK complexes. Phosphorylations of cyclin D3 do not appear to be involved in TSH-dependent cyclin D3-CDK4 assembly in thyrocytes, since all the main phosphorylated and unphosphorylated forms of cyclin D3 separated by twodimensional (2D) gel electrophoresis were found in unaltered relative proportions in CDK4 complexes [91]. Moreover, combined mutations of a series of putative phosphorylation sites of cyclin D3 (T283A, T117A, S133A, S264A) did not affect its binding to CDK4 and CDK4 activation in $\mathrm{CHO}$ cells (Bockstaele, unpublished data).

\section{INK4}

Presence of INK4 proteins obviously affects D-type cyclinCDK association [105]. Parry and collaborators reported that overexpression of $\mathrm{p} 21$ can promote the association of D-type cyclins with CDKs by counteracting their binding to INK4 proteins [106]. Conversely, increased expression of p15 in response to TGF $\beta$ [107-109], ERK-dependent p16 up-regulation [110], or p18 up-regulation by progestin [111] destabilize D-type cyclin-CDK complexes and mobilize p27. Defective p16 expression in tumor cells is thus very likely to contribute to constitutive cyclin D3CDK4/6 assembly as we observe it in glioma T98G cells [82]. However, INK4 proteins are not generally down-regulated by mitogenic stimulations, and thus are unlikely involved in stimulated assembly of D-type cyclin-CDK complexes. Interestingly, a phosphorylation (Ser152) of p16 correlates with CDK4 association in human fibroblasts [112]. Regulation of this phosphorylation and its impact on p16-binding to CDK4 remain to be determined.

\section{Chaperone proteins}

Assembly of D-type cyclin and CDK4 likely depends on proper folding of both subunits. Binding to the chaperone HSP90 via p50cdc37 stabilizes CDK4 $[113,114]$, competes with p16 and thus would facilitate the assembly of a complex between CDK4 and cyclin D1 [115]. Accordingly, mutations of CDK4 within its ATP-binding domain (G15A and G18A), which preclude Cdc37-CDK4 complex formation, also greatly reduce binding of CDK4 to cyclin D1 [116]. Upon release from Cdc37-HSP90 interaction, properly folded newly synthesized CDK4 could thus directly assemble with D-type cyclins, preferentially to the 
more inert pool of INK4-bound CDK4. Once again, mitogenic regulation at this level has not been defined. In another recent development, Diehl and collaborators have identified Hsc70 as at least one of the probable missing component of the active cyclin D1-CDK4 holoenzyme of NIH 3T3 cells [117]. Hsc70-cyclin D1 interaction is stimulated by serum and would promote stabilization of newly synthesized cyclin D1, thereby increasing its availability for assembly with CDK4. Nevertheless, Hsc70 does not appear to assemble the cyclin D1-CDK4 complex. Furthermore, interaction between Hsc70 and endogenously expressed cyclin D1 was hardly detectable [117]. In dog thyrocytes stimulated by TSH, we also easily identified Hsc70 from two-dimensional gel separation of co-immunoprecipitations by cyclin D3 and CDK4 antibodies. Unfortunately, unspecific association of Hsc70 to mock immunoprecipitations (done with normal mouse serum) that could not be displaced by high salt washings, as well as our failure to detect endogenously expressed cyclin D3 and CDK4 in Hsc70 immunoprecipitations, have prevented us from further investigating this interaction (Paternot, unpublished results).

\section{SEI-I}

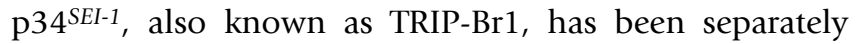
identified as a p16 binding protein [118] and as a transcriptional regulator that can functionally contact DP-1 and co-activate E2F-1/DP-1 transcriptional activity [119]. NIH 3T3 cells engineered to overexpress SEI-1 are anchorage-independent and tumorigenic, and amplification of SEI-1 gene is commonly detected in ovarian cancers [120]. SEI-1 is induced by serum, and its ectopic expression allows the formation of active CDK4 complexes that contain both p16 and cyclin D1. SEI-1 might thus facilitate the assembly of cyclin D1-CDK4 complexes by counteracting inhibitory effects of INK4 proteins [118]. Physiological relevance of this interesting mechanism remained doubtful, however, since complexes containing both p16 and cyclin D1 are not generally observed [60]. Indeed, the same authors showed in a subsequent study that expression of p16 blocks the pRb-kinase activity associated with ectopically expressed SEI-1 [94]. Ablation of SEI-1/TRIPBrI and TRIP-Br2 expression suppresses serum-induced cyclin E expression and prevents S-phase entry [121]. Whether this results from an impairment of CDK4 complex activation or of E2F-dependent transcription has yet to be defined.

\section{Gankyrin}

The oncoprotein gankyrin [122] is a seven-ankyrin-repeat protein that interacts with $\mathrm{pRb}$, increases phosphorylation of $\mathrm{pRb}$ by CDK4, and also increases the binding of p53 to MDM2 [123]. In hepatocytes, gankyrin expression is increased by mitogenic stimulation [124]. A search for interaction partners of transfected gankyrin has identified
CDK4 [125], and gankyrin competes with p16 for binding to CDK4 in reconstitution experiments [126]. It is not known if gankyrin binds to monomeric CDK4 or CDK4 complexed with D-type cyclins.

\section{Fbxo7}

Recently, the F-box protein Fbxo7 was identified in a twohybrid yeast screen using the viral cyclin of Herpesvirus saimiri as a bait [127]. Fbxo7 turned out to specifically interact in vitro and in intact cells with CDK6 (but not CDK4). Whereas knockdown of Fbxo7 reduces p27 expression and association of CDK6 with D-type cyclins, Fbxo7 fails to assemble cyclin-CDK6 complexes in vitro, and ectopic expression of Fbxo7 only moderately enhances CDK6 association with D-type cyclins and pRbkinase activity. Despite this rather modest effect, overexpression of Fbxo7 transforms NIH 3T3 cells in a CDK6dependent manner [127], which does not rule out an implication of other Fbxo7 interactors. Regulation of Fbxo7 by mitogenic factors was not reported.

To conclude, the assembly of D-type cyclin-CDK4/6 complexes is a highly regulated process. Only p21 or p27 have been found to be stoichiometrically present in these complexes. However, they are not required for the assembly of D-type cyclin-CDK complexes, though they can obviously stabilize them. INK4 proteins clearly restrict cyclin-CDK assembly, but regulation at this level has not been determined. Mainly in overexpression systems, other interesting interactors of CDK4/6 or D-type cyclins have been demonstrated. They could influence the conformation of the cyclin or CDK subunit, and facilitate either the release of CDK4/6 from its complex with inhibitory INK4 proteins or the association of the CDK with the cyclin. Nevertheless, much additional experimental evidence is needed to demonstrate the physiological relevance and regulation of these new interactions. Molecular masses of the D-typecyclin-CDK4/6 and their complex with p21/p27 are predicted to be about 70 and $100 \mathrm{kDa}$, respectively. Such complexes do exist in intact cells. On the other hand, the missing component(s) of the abundant $150-200 \mathrm{kDa}$ active CDK4/ 6 complexes that have been demonstrated in various cell systems remain to be identified.

\section{Regulated nuclear translocation of D-type cyclin-CDK4 complexes}

D-type cyclin-CDK4/6 complexes should accumulate in the nucleus in order to phosphorylate their nuclear substrates including pRb, p107 and p130. Moreover, the activity of CDK4/ 6 requires their activating phosphorylation on Thr172/177 by the CDK-activating kinase (CAK), which is a nuclear holoenzyme (but see discussion below). Accordingly, a mutant of cyclin D1 that assembles with CDK4 but prevents its nuclear localization (but also its activation by CAK in vitro) dominantly inhibits the 
ability of NIH 3T3 cells to enter S phase [128]. Conversely, ectopic expression (together with CDK4) of a nucleus-targeted variant of cyclin D1 but not of wild-type cyclin D1 promotes reentry of cardiomyocytes into cell cycle, suggesting a critical role of cyclin D1 nuclear import [129]. Recently, the oncogenic potential of mutations that prevent the nuclear export of cyclin D1 has been demonstrated $[54,130]$. Nuclear translocation of cyclin D1 and CDK4 during mitogenic processes has been observed in vivo, including in rat liver regeneration [131] and in the estrogen-induced proliferation of uterine epithelium [132].

D-type cyclins and CDK4/6 do not possess obvious nuclear localization sequences. Furthermore, depending on its Thr286 phosphorylation by GSK3 $\beta$ which allows its binding to the exportin CRM1, cyclin D1 is exported to the cytoplasm during S-phase in fibroblasts [133]. Other CDK4/6 binding proteins including INK4 proteins $[34,107]$ and Cdc37 [113] are mostly cytoplasmic proteins. By contrasts, Cip/Kip proteins contain a well characterized bipartite nuclear localization signal (NLS) in their C-terminus. Enforced expressions of p21, p27 and p57 were thus demonstrated to localize D-type cyclin-CDK complexes to the nucleus $[82,90,107,134]$. These proteins really determine the location of $\mathrm{CDK} 4$, as the deletion of the NLS of p21 and p27 relocalize CDK4 to the cytoplasm $[82,90,107]$. In NIH 3 T3 cells, p21 promotes the nuclear accumulation of cyclin D1 by preventing its association with CRM1 [135]. Like its assembly [79], the nuclear accumulation of cyclin D1-CDK4 appears to depend on MEK activity in NIH 3T3 cells [136].

To our knowledge, dog thyrocyte primary cultures have provided the first example of a nuclear translocation of endogenously expressed CDK4 in response to various mitogenic stimulations, including TSH and cAMP, growth factors and phorbol esters [70]. CDK4 nuclear translocation elicited by TSH (CAMP) correlates in individual cells with G1 and S-phase progression [70] and depends on the presence of comitogenic factors (insulin and carbachol) $[83,84]$. In thyrocytes stimulated by growth factors, CDK4 nuclear import perfectly correlates in individual cells with binding to cyclin D1 and up regulated nuclear p21 [45], whereas it is associated with cyclin D3 and nuclear accumulation of p27 in TSH-stimulated cells $[85,91]$. The inhibition by TGF $\beta$ of TSH-elicited nuclear import of both CDK4 and cyclin D3 is explained by their reduced association with nuclear p27. Interestingly, the TSH-dependent assembly of cyclin D3-CDK4 complexes is not affected by TGF $\beta$, which dissociates the nuclear import from the assembly, and points out the critical role of p27 in the subcellular location but not in the assembly of cyclin D3CDK4 $[85,91]$. Intriguingly, the nuclear translocation of cyclin D3 in thyrocytes is associated with the unmasking of its DCS-22 epitope (aa 241-260), which suggests a conformational change of cyclin D3 or a modification of its interaction with other proteins $[70,85]$. At variance with the situation described for the export of Thr286-phosphorylated cyclin D1 in fibroblasts [133], cyclin D3 steadily accumulates in nuclei during $S$ and $G_{2}$-phases [70], and the phosphorylation of cyclin D3 at Thr283 by GSK3 $\beta$ does not signal its nuclear export [137].

In many cell systems, late $G_{1}$ phase progression depends on the activity of the calcium-binding protein calmodulin. Pharmacological inhibition of calmodulin in NRK fibroblasts inhibits the activity of cyclin D1-CDK4 complexes by inducing their translocation to the cytoplasm, providing another early example of regulation of D-type cyclin-CDK4 complex localization dissociated from the modulation of its assembly [138]. This calmodulindependent nuclear accumulation of cyclin D1-CDK4-p21 complexes appears to depend on a direct calcium-dependent binding of p21 to calmodulin [139].

As p21 and p27 clearly determine the subcellular location of D-type-cyclin-CDK4 complexes, posttranslational modifications that alter the nuclear location of $\mathrm{p} 21$ or $\mathrm{p} 27$ should also affect the localization of CDK4 and its activity. The impact on p21 subcellular location of its Thr145phosphorylation by overactivated Akt or Pim1 remains controversial [140-143]. The major phosphorylation of p27kip 1 at Ser10 [144] has been reported to cause the nuclear export of p27kip1 during G1 phase progression in fibroblast cell lines [145-147]. The inactivation of p27kip1 by its cytoplasmic mislocalization in different breast cancer cell lines is caused by $\mathrm{p} 27^{\mathrm{kip} 1}$ phosphorylation within the NLS at Thr157 by overactivated Akt/PKB [148-150]. Thr157 phosphorylation of p27 by cytoplasmic Akt, which prevents p27 binding to importin $\alpha$ and thus nucleus re-entry, appears itself to depend on prior Ser10phosphorylation of p27 required for its nuclear export [151]. This relocalization of p27 into the cytoplasm is believed to critically contribute to the activation of cyclin E-CDK2. Unfortunately, its impact on CDK4 complex localization and activity was not investigated in the above referenced studies. Ser10 phosphorylation of p27 is unlikely to be sufficient for nucleus export. Nuclear p27 is abundantly phosphorylated at Ser10 in dog thyrocytes and p27-transfected CHO cells [82,91]. In dog thyrocytes, the phosphorylation profile of p27 (as resolved by isoelectric focusing separation) and its Ser10-phosphorylation are not consistently modulated by CAMP, TGF $\beta$, insulin, growth factors, or pharmacological inhibition of MEK- or PI3-kinase-dependent signalling, and all the (un)phosphorylated forms of p27 are found in unaltered proportion in cyclin D3-CDK4 complexes [82,91]. 
To conclude, the instrumental role of the up-regulation by mitogenic treatments of either p21 or p27 in the required nuclear import of D-type cyclin-CDK4 complexes is well demonstrated in a variety of cell systems. It appears to be dominant over mechanisms that promote nucleus export of CDK4 and D-type cyclins, including the GSK3 $\beta$ dependent phosphorylation of cyclin D1. A significant role for posttranslational modifications of p21 and p27 in the regulation of this process has yet to be firmly demonstrated.

\section{Regulated activity of D-type cyclin-CDK4 complexes}

The assembly of D-type cyclin-CDK4/6 complexes and even their nuclear location are not sufficient for their catalytic activity. Upon mitogenic stimulation of quiescent cells, appearance of the pRb-kinase activity of CDK4 is often delayed compared to the formation of D-type cyclin-CDK4 complexes $[80,82,131,152,153]$. Both processes are clearly dissociated in other situations, which include the inhibition of the activity of D-type cyclinCDK4 complexes by cAMP or rapamycin in mouse macrophages [75], contact inhibition in 3Y1 rat fibroblasts [154], senescence of human fibroblasts [155], antiestrogen treatment of MCF-7 breast cancer cells [156], calmodulin inhibitors in human fibroblasts [157], and arrest of cAMP-dependent mitogenic stimulation in dog thyrocytes by forskolin deprivation $[158,159]$, TGF $\beta$ [91] or inactivation of Rho proteins by Clostridium toxin B [160].

Inhibition by p21 or p27 is the most generally proposed mechanism to explain the inactivity of D-type cyclinCDK4 complexes $[59,63,161]$. Thus, the activation of cyclin D1-CDK4 complexes during G1 phase progression depends on p27 disappearance [80,153], and is prevented by up-regulation of p27 [75,154] or p21 [155,156]. This obviously contrasts with the positive roles (stabilization and nuclear anchoring) of these "inhibitors" on D-type cyclin-CDK4 complexes, and the frequent observation that they can support the pRb-kinase activity of CDK4 [162]. Whereas $\mathrm{G}_{1}$ arrest by cAMP in mouse macrophages is associated with p27 up-regulation which inhibits cyclin D1-CDK4 activity [75], in the cAMP-dependent $\mathrm{G}_{1}$-phase progression of dog thyrocytes, an apparently similar elevation of p27 concentration allows the nuclear import and activation of cyclin D3-CDK4 complexes, and both processes are prevented by TGF $\beta$ which inhibits the binding of this complex to p27 [91]. Similarly, inhibition of cyclin D1-CDK4 activity has been explained either by increased [156] or decreased [104] binding of p21.

Labaer et al [90](in the case of p21 but not of p27) and Blain et al [89](in the case of p27 but not of p21) have interestingly shown that such opposite roles of CDK "inhibitors" could depend on their stoichiometry relative to a D-type cyclin in CDK4 complexes, as initially shown for the dual action of p21 on cyclin A-CDK2 [163]. Nevertheless, structural studies indicate that cyclin A-CDK2 complexes can accommodate only one molecule of p21 or p27, which fully inhibits the activity [164-166]. Moreover, according to Pledger and collaborators, only the minor fraction of cyclin D3-CDK4 complexes devoid of $\mathrm{Cip} / \mathrm{Kip}$ proteins is active $[93,95]$. Our analysis of the impact of graded concentrations of p27 relative to cyclin D3 and CDK4 in CHO and Sf9 cells and in vitro, as well as the comparison of their relative expression levels in native systems where p27 supports or prevents CDK4 activity, fully confirm the "stoichiometric" model [82]. This implies two types of cyclin D3-CDK4-p27 complexes depending on relative p27 concentrations: the first comprising a low stoichiometry binding of p 27 and displaying a pRb-kinase activity, and the second, inactive due to additional p27 molecule(s). Whereas the association of p27 to CDK complexes is generally believed to depend on its binding to the cyclin $[60,166]$, we have found both in Sf9 and CHO cells, that p27 can avidly form binary complexes with CDK4 in the absence of a D-type cyclin [82]. In native systems, we also observed a persistence of $\mathrm{p} 27$ CDK4 complexes after the disappearance of labile D-type cyclins provoked by protein synthesis inhibition $[82,159]$. This association of p27 with cyclin-free CDK4 in intact cells is consistent with the model of different p27-binding modes permitting the association of several p27 molecules to D-type cyclin-CDK4 complexes.

The D-type cyclins/p27 ratio can thus contribute to determine the cell responsiveness to mitogens or growth inhibitory factors, which in turn act to modify this equilibrium to levels that allow, or prevent, the concerted activation of CDKs leading to S-phase entry [162]. In some circumstances, as in quiescent dog thyrocytes which express high amounts of cyclin D3 [70] but low levels of p27 and p21, p27 (in response to TSH) or p21 (in response to growth factors [45]) rather than D-type cyclins may have to be upregulated to facilitate CDK4 activation. Similarly in mammary gland and prostate of p27-null mice, epithelial cell proliferation was reported to be impaired, whereas p27 haplo-insufficiency accelerated cyclin D1-dependent transformation, which was prevented by normal p27 expression [167-169].

Some modulations of the activity of D-type cyclin-CDK4 complexes cannot be explained by modifications of their association with p21 or p27 $[82,157,158,160]$. For instance, in dog thyrocytes the withdrawal of the cAMP stimulation rapidly arrests the entry of cells in S-phase and $\mathrm{pRb}$ phosphorylation but does not reverse the formation of nuclear cyclin D3-CDK4-p27 complexes [84,158]. 


\section{Regulated phosphorylation of CDK4}

Phosphorylation is the least studied level of regulation of CDK4. An inhibitory phosphorylation of CDK4 on Tyr17 was reported in UV irradiation-induced $G_{1}$ arrest [170] or during cell's arrest in quiescence [171] or in response to TGF $\beta$ [172]. However, the group of Sherr failed to detect a tyrosine-phosphorylation of CDK4 [77,173], in agreement with the observation that CDK4, unlike CDK1 and CDK2, is not an in vitro substrate of the Wee1 CDK tyrosine kinase [174]. On the other hand, by analysing human D-type cyclin-CDK4 expressed in insect cells through baculoviral infection, Kato et al. have demonstrated that the activity of CDK4 requires its phosphorylation on Thr172 [77] within the activation loop. Thr172-phosphorylation of CDK4 requires its binding to a D-type cyclin, while T172A mutation of CDK4 does not affect its binding to the cyclin [77]. Furthermore, this group showed that mammalian cell extracts possess a CDK4-activating kinase activity which was ascribed to CAK (cyclin H-CDK7) on the basis of the immunodepletion of this in vitro activity by a polyclonal CDK7 antibody [175]. Nevertheless, the activity of nuclear CAK (CDK7) complexes has generally been found to be constitutive and non-regulated during cell cycle or mitogenic stimulations [82,175-177]. Thr172-phosphorylation of CDK4 is thus assumed to passively result from CDK4 binding to a cyclin and subsequent nuclear import. When it is inhibited within the cyclin D1-CDK4 complex by cAMP or contact inhibition, this was ascribed to increased binding of p27 [75,154], which has been found to prevent the activating phosphorylation of CDKs by CAK in vitro [75,178-181].

Despite the fact that it is required for CDK4 activity $[77,82]$, the activating Thr172 phosphorylation of CDK4 has been infrequently investigated because of lack of methodological tools. We have recently shown that the high-resolution power of the two-dimensional (2D) gel electrophoresis (isoelectric focusing and SDS-PAGE) allows one to separate several phosphorylated and nonphosphorylated forms of CDKs and to visualize their relative proportions in the different complexes $[82,91,182]$. At variance with CDK2 [182], only one major single phosphorylated form of CDK4 is observed in a variety of cell types, including dog and human thyrocytes, human fibroblasts, T98G glioma cells, Rat2 fibroblasts,... ([82,91,100], and our unpublished results). We have identified this main phosphorylated form of CDK4 as comprising the activating Thr172 phosphorylation, by the analysis of the CDK4 T172A mutant, in vitro phosphorylation by recombinant CAK, as well as the utilization of first samples of a trial production (not yet commercialized) of a Thr172 phosphospecific CDK4 antibody by Cell Signalling Technology Inc. [82]. These tools were also useful for the analysis of the corresponding (Thr177) phosphorylation of CDK6 [82]. In those cells, no stoichiometrically (biologically) significant phosphorylated form of CDK4 (except a very minor form that comprises the Thr172 phosphorylation and a possible second undefined one) could contain the inhibitory Tyr17 phosphorylation. In human fibroblasts (even after UV irradiation (Kooken, unpublished results)), the lack of Tyr17phosphorylated CDK4 contrasts with the major phosphorylation of CDK2 on Tyr15 [182], implying that activation of CDK4 and CDK2 must very differently depend on Cdc25 phosphatases.

As demonstrated by 2D-gel separation of CDK4, the cAMP-dependent cell cycle regulation and its inhibition by TGF $\beta$ in dog thyrocytes have provided the first examples of a regulation of the activating Thr172-phosphorylation of CDK4 independently of changes in its association with cyclins and CDK " inhibitors » [82,91,159]. Upon arrest of forskolin stimulation, which induces the rapid inactivation of cyclin D3-CDK4-p27 complexes without preventing their continued formation, Thr172-phosphorylation of CDK4 disappears from the cyclin D3 complexes. The association of CDK4 with cyclin D3 and its activating phosphorylation within this complex are thus separately controlled by cAMP [159]. The strong inhibition by TGF $\beta$ of the activity of cyclin D3-CDK4 complexes in TSH (cAMP)-stimulated dog thyrocytes is also explained by decreased Thr172-phosphorylation of CDK4, even within the residual cyclin D3-CDK4 complexes that remain associated with p27 [82,91]. The activating phosphorylation of CDK4 thus integrates the opposite cell cycle controls by cAMP and TGF $\beta$ after formation of cyclin D3-CDK4 complexes. Furthermore, in T98G cells and Rat 2 cells (unpublished data), serum stimulation strongly activates constitutively formed cyclin D3CDK4 complexes at least in part by directly stimulating the Thr172-phosphorylation of CDK4 [82]. This would generalize the new concept that Thr172-phosphorylation could be a latest regulated step that determines the catalytic activity of CDK4, the phosphorylation of Rb family proteins and thus the passage through the $G_{1}$ phase restriction point.

In all those examples, modifications of p27-binding to CDK4 complexes were unlikely to explain the modulations of CDK4 phosphorylation. Indeed, the proportion of Thr172-phosphorylated CDK4 is similarly enriched in D-type cyclin complexes and in CDK4 bound to p27 or p21 $[45,82,91,159]$, even at high relative expression levels of p27 that preclude CDK4 activity [82]. At variance with previous conclusions [75], p27 does not inhibit the activity of D-type cyclin-CDK4 complexes by preventing the activating phosphorylation of CDK4. 


\section{Regulated CDK4-activating kinase(s) ?}

The mechanisms involved in the regulation of the phosphorylation of cyclin D3-bound CDK4 remain enigmatic. In mammalian cells, the major CAK activity that phosphorylates CDK4/6, CDK2 and CDK1 is considered to be constituted of cyclin H-CDK7-MAT1, which are also subunits of transcription factor II H $[181,183,184]$. In principle, (anti)mitogenic signalling cascades might regulate the activity of CAK, its substrate specificity or its access to CDK4. However, we got no evidence of a regulation of CAK (CDK7 complex) expression or activity in dog thyrocytes and T98G cells [82], as most often reported [175177]. This might suggest that constitutive CAK (CDK7) complexes could not be instrumental in the regulated phosphorylation of CDK4. In addition to the observation discussed above that Thr172-phosphorylation of CDK4 is not prevented by inhibitory concentrations of $\mathrm{p} 27$, other arguments call for a reconsideration of CDK4-activating kinase(s). Whereas CDK7 activity is nuclear, deletion of p27 NLS sequence relocalizes most of cyclin D3-CDK4p27 complexes in the cytoplasm without impairing phosphorylation of p27-bound CDK4 [82]. As analysed in the same cyclin D3 co-immunoprecipitations in T98G glioma cells, serum stimulates the activating phosphorylation of CDK4 but not that of the related CDK6 [82]. Nevertheless, the latter appears as a better substrate for recombinant CAK (cyclin H-CDK7-Mat1) in the same experiments [82], consistent with observations by others who succeeded to readily phosphorylate CDK2 and CDK6, but not different CDK4 preparations, using recombinant CAK $[153,180]$.

Although CAK (CDK7) can unambiguously phosphorylate and activate cyclin D3-bound CDK4 in vitro, other regulated CDK4-activating kinase(s) might thus remain to be discovered. They might even be different in distinct mitogenic stimulations and selectively target CDK4 complexed to cyclin D3 or cyclin D1. Some observations cannot be easily explained by only one kinase activating the different D-type cyclin-CDK4 complexes. Indeed, how could TGF $\beta$ selectively inhibit the activating phosphorylation of CDK4 bound to cyclin D3 in dog thyrocytes stimulated by TSH, without affecting the activity and phosphorylation of CDK4 stimulated by EGF [91]? How could EGF stimulate the phosphorylation and activity of CDK4 bound to cyclin D1 in human thyrocytes, but not the activity of abundant cyclin D3-CDK4 complexes, which were specifically activated by TSH [100]?

Recent studies have also pointed out the Thr160 phosphorylation of CDK2 as a direct target of treatments that prevent S-phase entry [185-188]. In some of these studies, the activation of CDK4 $[185,186]$ and/or the in vitro assayed activity of CDK7 $[185,188]$ remain unaffected, leading their authors to suggest the involvement of distinct CAK activities. In D. melanogaster, CDK7 is required for the activation of CDK1 complexes but not for phosphorylation and activation of CDK2-cyclin E [189]. At variance with nuclear cyclin H-CDK7 of animal cells, the cytoplasmic monomeric Cak1p of budding yeast [190] preferentially phosphorylates monomeric CDK2 and CDK6 in vitro, and CDK inhibitors including p 27 do not block this activity [180]. Several monomeric CAKs with distinct substrate specificities coexist with CDK7 orthologs in plants [191,192]. In human cells, a small distinct CAK activity was enriched [193], and a candidate nuclear p42 CAK was recently cloned [194]. Although the CDK2 phosphorylating activity of this p42 "CAK" has been disputed recently [195], it seems that the debate about the nature of mammalian CAK(s) $[181,183,184]$ is not coming closer to its end.

\section{Conclusion}

The activation of CDK4 is a peculiarly complex process requiring different successive steps, which are distinguished by their independent regulations. This allows to better understand how CDK4 can function at the restriction point as a master integrator of various mitogenic and antimitogenic controls of the cell cycle. A few models, including the physiologically relevant example of the thyroid primary culture system, have allowed to dissociate the regulated assembly of D-type cyclin-CDK4 complexes from the accumulation of their individual partners, the nuclear import of these complexes from their assembly, and the activating phosphorylation of CDK4 from the formation and nuclear accumulation of the D-type cyclinCDK4-p27/p21 holoenzyme (Figure 1). We have identified this last step as an ultimate regulatory target determining CDK4 activity, $\mathrm{pRb}$ phosphorylation and the passage through the $G_{1}$ phase restriction point. Some evidence is emerging that the activation process of the six possible cyclin D1/2/3-CDK4/6 complexes could be subject to partly different regulatory mechanisms. Cyclin D3CDK6 complexes appears to be especially resistant to inhibition by p16 [196] and p27 [197]. In T98G glioma cells, serum stimulates the phosphorylation of cyclin D3bound CDK4 but not cyclin D3-bound CDK6 [82]. In thyrocytes, the distinct mitogenic pathways of growth factors or TSH appear to be channeled to preferentially activate and utilize CDK4 complexed to either cyclin D1 or cyclin D3 $[45,70,100]$ (Figure 1). This leads to partly different phosphorylations of $\mathrm{pRb}$, which might differentially impact $\mathrm{pRb}$ function in the transcriptional regulation of genes involved in cell cycle or differentiation $[45,100]$.

The visualization of the phosphorylation profiles, as resolved using 2D-gel electrophoresis, of CDK4 [82], CDK2 [182] and CDK1 (Kooken and Coulonval, unpublished results) has illustrated the different logics of their regulations. Cyclin-CDK1/CDK2 accumulate as a reser- 


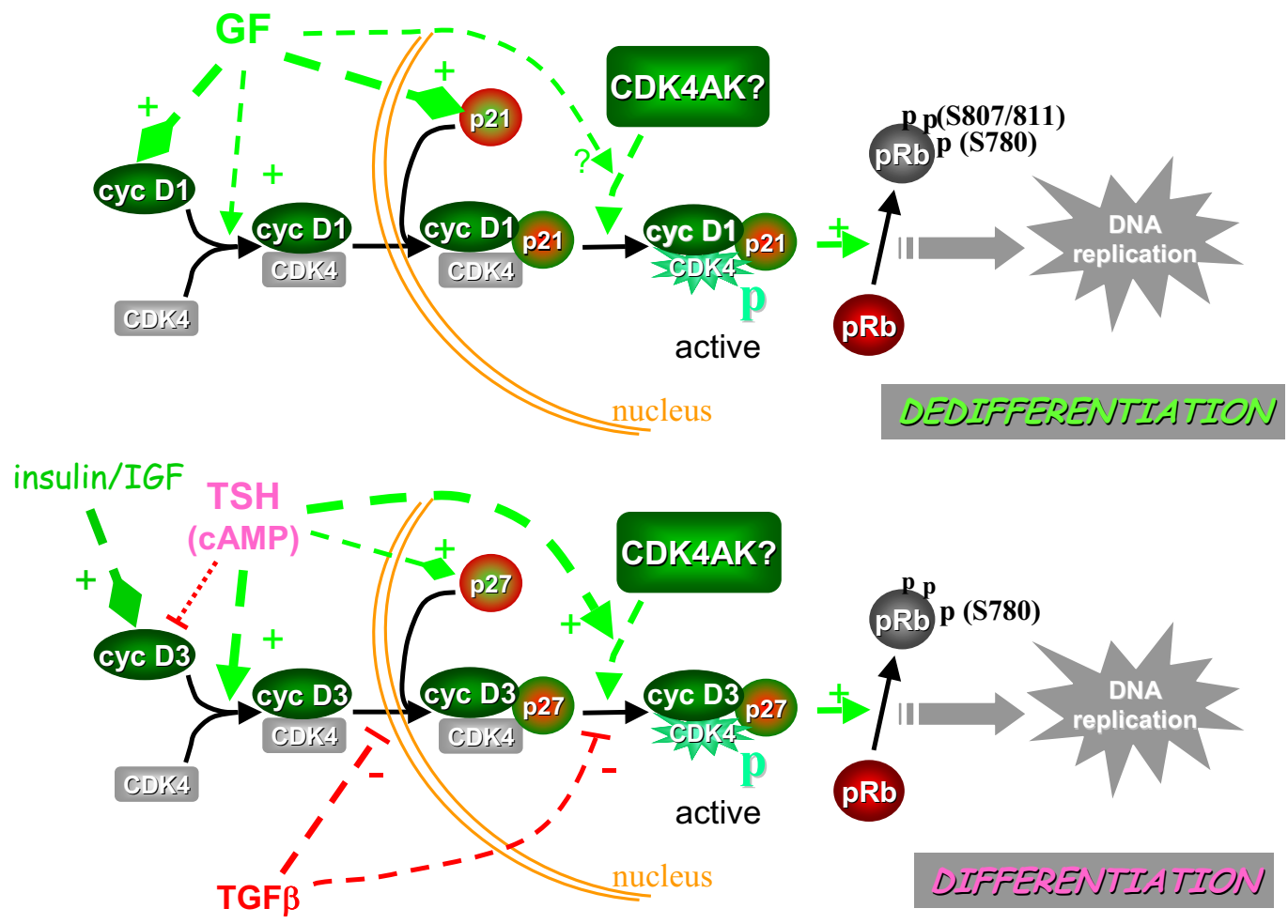

\section{Figure I}

CDK4 regulation: the example of canine thyroid primary cultures. Two distinct mitogenic modes coexist in dog thyrocytes and are differentially associated with differentiation expression. Growth factors (GF) activate CDK4 as in other systems, mainly by inducing cyclin DI and also P2I, which stabilizes the cyclin DI-CDK4 complex in the nucleus. The differentiation-associated cell cycle activation by TSH and cAMP is adjunctive to this basic control. It utilizes cyclin D3 synthesized in response to insulin or IGF-I, and p27. cAMP activates CDK4 by promoting the assembly of the cyclin D3-CDK4 complex, its association with nuclear p27, and finally the activating Thr 172-phosphorylation of CDK4 within this complex by an undefined CDK4 activating kinase (CDK4AK). Activation of CDK4 complexed to cyclin DI or cyclin D3 in these parallel mitogenic stimulations leads to partially different site-specificity of pRb-kinase activity. In this system, TGF $\beta$ selectively inhibits the cAMP-dependent activation of cyclin D3-CDK4, not by impairing the formation of this complex, but by preventing its binding to nuclear p27, as well as by inhibiting CDK4 phosphorylation within residual p27-bound cyclin D3-CDK4 complexes. The dog thyrocyte model illustrates the dissociation of the regulated assembly of D-type cyclin-CDK 4 complexes from the accumulation of their subunits, the dissociation of the nuclear import of these complexes from their assembly, and the dissociation of the rate-limiting phosphorylation of CDK4 from the formation and nuclear accumulation of the D-type cyclin-CDK4-p27/p2 I holoenzyme. Diamond arrowheads represent inductions; the other dashed arrows are activations $(+)$ or inhibitions (-). 
voir of inactive complexes containing both activating (Thr161/160) and inhibitory (Tyr15 and Thr14) phosphorylations until their activation by dephosphorylation of the inhibitory residues by Cdc25 phosphatases. On the other hand, CDK4 activity could not be generally restricted by substantial Tyr-phosphorylation, but by lack of activating phosphorylation, at variance with the corresponding phosphorylations of CDK2/1 by CAK which are not thought to be rate-limiting.

CDK4 activity is crucial in various tumorigenesis models and appears as a very attractive target for cancer therapy [198]. As discussed in this overview, increased expression of a D-type cyclin is clearly not sufficient to activate CDK4, which likely explains the lack of relationship between cyclin D1 overexpression and CDK4 activity in neoplastic epithelial cell lines [199]. Mechanisms responsible for the regulation of the assembly and activation of D-type cyclin-CDK complexes are crucial but remain largely enigmatic. They constitute obvious targets for oncogenic mechanisms. Their elucidation thus remains a major challenge that might lead to the discovery of new therapeutic targets.

\section{Competing interests}

The author(s) declare that they have no competing interests.

\section{Acknowledgements}

The authors are listed by alphabetical order and equally contributed to the definition of CDK4 regulation. Work performed in authors' laboratory was supported by grants from the Belgian Federation against Cancer, the Communauté française de Belgique - Actions de Recherches Concertées, the Belgian Fund for Scientific Medical Research (FRSM), the National Fund for Scientific Research (FNRS, Belgium) and Télévie. LB is a research fellow of the Télévie, HK is a fellow of the Fonds pour la Formation à la Recherche dans I'Industrie et l'Agriculture (FRIA). S.B. and P.P.R. are respectively Senior Research Assistant and Research Associate of the FNRS. The continued interest, helpful discussions and moral support by Professor Jacques Dumont are deeply acknowledged.

\section{References}

I. Malumbres M, Sotillo R, Santamaria D, Galan J, Cerezo A, Ortega S, Dubus $P$, Barbacid $M$ : Mammalian cells cycle without the $D$ type cyclin-dependent kinases Cdk4 and Cdk6. Cell 2004, I I 8:493-504.

2. Kozar K, Ciemerych MA, Rebel VI, Shigematsu H, Zagozdzon A, Sicinska E, Geng Y, Yu Q, Bhattacharya S, Bronson RT, Akashi K, Sicinski $\mathrm{P}$ : Mouse development and cell proliferation in the absence of D-cyclins. Cell 2004, I | 8:477-49|.

3. Geng Y, Yu Q, Sicinska E, Das M, Schneider JE, Bhattacharya S, Rideout WM, Bronson RT, Gardner H, Sicinski P: Cyclin E ablation in the mouse. Cell 2003, I | 4:43 I-443.

4. Parisi T, Beck AR, Rougier N, McNeil T, Lucian L, Werb Z, Amati B: Cyclins EI and E2 are required for endoreplication in placental trophoblast giant cells. EMBO J 2003, 22:4794-4803.

5. Berthet C, Aleem E, Coppola V, Tessarollo L, Kaldis P: Cdk2 knockout mice are viable. Curr Biol 2003, I 3: I775-। 785.

6. Ortega S, Prieto I, Odajima J, Martin A, Dubus P, Sotillo R, Barbero JL, Malumbres $M$, Barbacid $M$ : Cyclin-dependent kinase 2 is essential for meiosis but not for mitotic cell division in mice. Nat Genet 2003, 35:25-3I.
7. Berthet C, Klarmann KD, Hilton MB, Suh HC, Keller JR, Kiyokawa H, Kaldis P: Combined loss of Cdk2 and Cdk4 results in embryonic lethality and Rb hypophosphorylation. Dev Cell 2006, 10:563-573.

8. Jirawatnotai S, Aziyu A, Osmundson EC, Moons DS, Zou X, Kineman $\mathrm{RD}$, Kiyokawa $\mathrm{H}$ : Cdk4 is indispensable for postnatal proliferation of the anterior pituitary. J Biol Chem 2004, 279:5। 100-51 106.

9. Kushner JA, Ciemerych MA, Sicinska E, Wartschow LM, Teta M, Long SY, Sicinski P, White MF: Cyclins D2 and DI are essential for postnatal pancreatic beta-cell growth. Mol Cell Biol 2005, 25:3752-3762.

10. Sicinska E, Aifantis I, Le Cam L, Swat W, Borowski C, Yu Q, Ferrando AA, Levin SD, Geng Y, von Boehmer H, Sicinski P: Requirement for cyclin D3 in lymphocyte development and $\mathrm{T}$ cell leukemias. Cancer Cell 2003, 4:45I-46I.

II. Sicinska E, Lee YM, Gits J, Shigematsu H, Yu Q, Rebel VI, Geng Y, Marshall CJ, Akashi K, Dorfman DM, Touw IP, Sicinski P: Essential role for cyclin D3 in G-CSF-driven expansion of neutrophil granulocytes. Mol Cell Biol 2006, 26:8052-8060.

12. Ciemerych MA, Sicinski P: Cell cycle in mouse development. Oncogene 2005, 24:2877-2898.

13. Aleem E, Kiyokawa H, Kaldis P: Cdc2-cyclin E complexes regulate the GI/S phase transition. Nat Cell Biol 2005, 7:831-836.

14. Deshpande A, Sicinski P, Hinds PW: Cyclins and cdks in development and cancer: a perspective. Oncogene 2005, 24:2909-29I5.

15. Rane SG, Dubus P, Mettus RV, Galbreath EJ, Boden G, Reddy EP, Barbacid $M$ : Loss of Cdk4 expression causes insulin-deficient diabetes and Cdk4 activation results in beta-islet cell hyperplasia. Nat Genet 1999, 22:44-52.

16. Lam EW, Glassford J, Banerji L, Thomas NS, Sicinski P, Klaus GG: Cyclin D3 compensates for loss of cyclin D2 in mouse B-lymphocytes activated via the antigen receptor and CD40. J Biol Chem 2000, 275:3479-3484.

17. Ciemerych MA, Kenney AM, Sicinska E, Kalaszczynska I, Bronson RT, Rowitch DH, Gardner H, Sicinski P: Development of mice expressing a single D-type cyclin. Genes Dev 2002, 1 6:3277-3289.

18. Carthon BC, Neumann CA, Das M, Pawlyk B, Li T, Geng Y, Sicinski P: Genetic replacement of cyclin $d I$ function in mouse development by cyclin d2. Mol Cell Biol 2005, 25: 1081-1088.

19. Berthet C, Kaldis P: Cdk2 and Cdk4 cooperatively control the expression of Cdc2. Cell Div 2006, I: 10 .

20. Grossel MJ, Hinds PW: Beyond the cell cycle: a new role for Cdk6 in differentiation. J Cell Biochem 2006, 97:485-493.

21. Bartkova J, Lukas J, Strauss M, Bartek J: Cyclin D3: requirement for GI/S transition and high abundance in quiescent tissues suggest a dual role in proliferation and differentiation. Oncogene 1998, I7:1027-1037.

22. Bartkova J, Rajpert-de Meyts E, Skakkebaek NE, Bartek J: D-type cyclins in adult human testis and testicular cancer: relation to cell type, proliferation, differentiation, and malignancy. J Pathol 1999, I 87:573-58I.

23. Hampl A, Pachernik J, Dvorak P: Levels and interactions of p27, cyclin D3, and CDK4 during the formation and maintenance of the corpus luteum in mice. Biol Reprod 2000, 62:1393-1401.

24. Petermann A, Hiromura K, Pippin J, Blonski M, Couser WG, Kopp J, Mundel P, Shankland SJ: Differential expression of d-type cyclins in podocytes in vitro and in vivo. Am J Pathol 2004 1 64:|4|7-|424

25. Kiess M, Gill RM, Hamel PA: Expression of the positive regulator of cell cycle progression, cyclin D3, is induced during differentiation of myoblasts into quiescent myotubes. Oncogene 1995, 10:159-166.

26. Rao SS, Kohtz DS: Positive and negative regulation of D-type cyclin expression in skeletal myoblasts by basic fibroblast growth factor and transforming growth factor beta. A role for cyclin D I in control of myoblast differentiation. J Biol Chem 1995, 270:4093-4100.

27. Phelps DE, Xiong Y: Regulation of cyclin-dependent kinase 4 during adipogenesis involves switching of cyclin $D$ subunits and concurrent binding of p I 8INK4c and p27Kip I. Cell Growth Differ 1998, 9:595-610

28. Ewen ME, Sluss HK, Sherr CJ, Matsushime H, Kato J, Livingston DM: Functional interactions of the retinoblastoma protein with mammalian D- type cyclins. Cell 1993, 73:487-497. 
29. Kato J, Matsushime H, Hiebert SW, Ewen ME, Sherr C): Direct binding of cyclin $D$ to the retinoblastoma gene product $(p R b)$ and pRb phosphorylation by the cyclin D-dependent kinase CDK4. Genes Dev 1993, 7:33I-342.

30. Weinberg RA: The retinoblastoma protein and cell cycle control. Cell 1995, 81:323-330.

31. Bartek J, Bartkova J, Lukas J: The retinoblastoma protein pathway and the restriction point. Curr Opin Cell Biol I996, 8:805-8I4

32. Farkas T, Hansen K, Holm K, Lukas J, Bartek J: Distinct phosphorylation events regulate p 130 - and p $107-$ mediated repression of E2F-4. J Biol Chem 2002, 277:2674I-26752.

33. Leng X, Noble M, Adams PD, Qin J, Harper JW: Reversal of growth suppression by p 107 via direct phosphorylation by cyclin DI/ cyclin-dependent kinase 4. Mol Cell Biol 2002, 22:2242-2254.

34. Lukas J, Parry D, Aagaard L, Mann DJ, Bartkova J, Strauss M, Peters G, Bartek J: Retinoblastoma-protein-dependent cell-cycle inhibition by the tumour suppressor p 16. Nature 1995, 375:503-506.

35. Lukas J, Bartkova J, Rohde M, Strauss M, Bartek J: Cyclin DI is dispensable for $G I$ control in retinoblastoma gene-deficient cells independently of cdk4 activity. Mol Cell Biol 1995, I5:2600-26II.

36. Medema RH, Herrera RE, Lam F, Weinberg RA: Growth suppression by pl6ink4 requires functional retinoblastoma protein. Proc Natl Acad Sci U S A 1995, 92:6289-6293.

37. Matsuura I, Denissova NG, Wang G, He D, Long J, Liu F: Cyclindependent kinases regulate the antiproliferative function of Smads. Nature 2004, 430:226-23I.

38. Voit R, Hoffmann M, Grummt I: Phosphorylation by GI-specific cdk-cyclin complexes activates the nucleolar transcription factor UBF. EMBO | 1999, 18: 189|-1899.

39. Liu E, Li X, Yan F, Zhao Q, Wu X: Cyclin-dependent kinases phosphorylate human Cdt I and induce its degradation. J Bio Chem 2004, 279: 17283-17288.

40. Shen R, Wang X, Drissi H, Liu F, O'Keefe RJ, Chen D: Cyclin DIcdk4 induce runx 2 ubiquitination and degradation. $J$ Biol Chem 2006, 28I: I6347-16353

41. Zacharek SJ, Xiong Y, Shumway SD: Negative regulation of TSCI-TSC2 by mammalian D-type cyclins. Cancer Res 2005, 65: II354-11360.

42. Sarcevic B, Lilischkis R, Sutherland RL: Differential phosphorylation of T-47D human breast cancer cell substrates by DID3-, E-, and A-type cyclin-CDK complexes. J Biol Chem 1997, 272:33327-33337.

43. Dong F, Cress WDJ, Agrawal D, Pledger WJ: The role of cyclin D3dependent kinase in the phosphorylation of pl30 in mouse BALB/c 3T3 fibroblasts. J Biol Chem 1998, 273:6190-6195.

44. Takaki T, Fukasawa K, Suzuki-Takahashi I, Semba K, Kitagawa M, Taya $\mathrm{Y}$, Hirai $\mathrm{H}$ : Preferences for phosphorylation sites in the retinoblastoma protein of D-type cyclin-dependent kinases, Cdk4 and Cdk6, in vitro. J Biochem (Tokyo) 2005, I37:38I-386.

45. Paternot S, Arsenijevic T, Coulonval K, Bockstaele L, Dumont JE, Roger PP: Distinct Specificities of pRb Phosphorylation by CDK4 Activated by Cyclin DI or Cyclin D3: Differential Involvement in the Distinct Mitogenic Modes of Thyroid Epithelial Cells. Cell Cycle 2006, 5:6I-70.

46. Sherr C], McCormick F: The RB and p53 pathways in cancer. Cancer Cell 2002, 2: 103-II2.

47. Ortega S, Malumbres M, Barbacid M: Cyclin D-dependent kinases, INK4 inhibitors and cancer. Biochim Biophys Acta 2002, 1602:73-87.

48. Zou X, Ray D, Aziyu A, Christov K, Boiko AD, Gudkov AV, Kiyokawa $\mathrm{H}$ : Cdk4 disruption renders primary mouse cells resistant to oncogenic transformation, leading to Arf/p53-independent senescence. Genes Dev 2002, 16:2923-2934.

49. Rodriguez-Puebla ML, Miliani de Marval PL, LaCava M, Moons DS, Kiyokawa $\mathrm{H}$, Conti $\mathrm{CJ}$ : Cdk4 deficiency inhibits skin tumor development but does not affect normal keratinocyte proliferation. Am J Pathol 2002, 16 I:405-4I I.

50. Tetsu O, McCormick F: Proliferation of cancer cells despite CDK2 inhibition. Cancer Cell 2003, 3:233-245.

5I. Miliani de Marval PL, Macias E, Rounbehler R, Sicinski P, Kiyokawa $\mathrm{H}$, Johnson DG, Conti C], Rodriguez-Puebla ML: Lack of cyclindependent kinase 4 inhibits c-myc tumorigenic activities in epithelial tissues. Mol Cell Biol 2004, 24:7538-7547.
52. Landis MW, Pawlyk BS, Li T, Sicinski P, Hinds PW: Cyclin DIdependent kinase activity in murine development and mammary tumorigenesis. Cancer Cell 2006, 9:13-22.

53. Yu O, Sicinska E, Geng Y, Ahnstrom M, Zagozdzon A, Kong Y, Gardner H, Kiyokawa H, Harris LN, Stal O, Sicinski P: Requirement for CDK4 kinase function in breast cancer. Cancer Cell 2006, 9:23-32.

54. Benzeno S, Lu F, Guo M, Barbash O, Zhang F, Herman JG, Klein PS, Rustgi A, Diehl JA: Identification of mutations that disrupt phosphorylation-dependent nuclear export of cyclin DI. Oncogene 2006, 25:629I-6303

55. Kaldis P, Ojala PM, Tong L, Makela TP, Solomon MI: CAK-independent activation of CDK6 by a viral cyclin. Mol Biol Cell 200I, 1 2:3987-3999.

56. Haller K, Wu Y, Derow E, Schmitt I, Jeang KT, Grassmann R: Physical interaction of human T-cell leukemia virus type I Tax with cyclin-dependent kinase 4 stimulates the phosphorylation of retinoblastoma protein. Mol Cell Biol 2002, 22:3327-3338.

57. $\mathrm{Li} \mathrm{J}, \mathrm{Li} \mathrm{H}$, Tsai MD: Direct binding of the N-terminus of HTLVI tax oncoprotein to cyclin-dependent kinase 4 is a dominant path to stimulate the kinase activity. Biochemistry 2003, 42:692I-6928.

58. Sherr Cl: D-type cyclins. Trends Biochem Sci 1995, 20:187-190.

59. Sherr CJ, Roberts JM: Inhibitors of mammalian GI cyclindependent kinases. Genes Dev 1995, 9:1 |49-1 63.

60. Hall M, Bates S, Peters G: Evidence for different modes of action of cyclin-dependent kinase inhibitors: pI5 and p/6 bind to kinases, p2I and p27 bind to cyclins. Oncogene 1995, I I:|58|-|588.

61. Pavletich NP: Mechanisms of cyclin-dependent kinase regulation: structures of Cdks, their cyclin activators, and Cip and INK4 inhibitors. J Mol Biol 1999, 287:82 I-828.

62. Hannon G], Beach D: pI5INK4B is a potential effector of TGFbeta-induced cell cycle arrest [see comments]. Nature 1994, 37 I:257-26I

63. Pei $\mathrm{XH}$, Xiong $\mathrm{Y}$ : Biochemical and cellular mechanisms of mammalian CDK inhibitors: a few unresolved issues. Oncogene 2005, 24:2787-2795.

64. Ewen ME, Sluss HK, Whitehouse LL, Livingston DM: TGF beta inhibition of Cdk4 synthesis is linked to cell cycle arrest. Cell 1993 , 74: $1009-1020$.

65. Kimura T, Van Keymeulen A, Golstein J, Fusco A, Dumont JE, Roger PP: Regulation of thyroid cell proliferation by thyrotropin and other factors : a critical evaluation of in vitro models. Endocr Rev 200I, 22:63I-656.

66. Roger PP, Christophe D, Dumont JE, Pirson I: The dog thyroid primary culture system: a model of the regulation of function, growth and differentiation expression by CAMP and other well-defined signaling cascades. Eur J Endocrinol 1997, 137:579-598.

67. Roger PP, Servais P, Dumont JE: Induction of DNA synthesis in dog thyrocytes in primary culture: synergistic effects of thyrotropin and cyclic AMP with epidermal growth factor and insulin. J Cell Physiol 1987, 130:58-67.

68. Roger PP, Baptist M, Dumont JE: A mechanism generating heterogeneity in thyroid epithelial cells: suppression of the thyrotropin/cAMP-dependent mitogenic pathway after cell division induced by cAMP-independent factors. / Cell Biol I 992, I I 7:383-393.

69. Lukas J, Bartkova J, Bartek J: Convergence of mitogenic signalling cascades from diverse classes of receptors at the cyclin D-cyclin-dependent kinase-pRb- controlled GI checkpoint. Mol Cell Biol 1996, 16:6917-6925.

70. Depoortere F, Van Keymeulen A, Lukas J, Costagliola S, Bartkova J, Dumont JE, Bartek J, Roger PP, Dremier S: A requirement for cyclin D3-cyclin-dependent kinase (cdk)-4 assembly in the cyclic adenosine monophosphate-dependent proliferation of thyrocytes. J Cell Biol 1998, I 40:1427-1439.

7I. Lamy F, Wilkin F, Baptist M, Posada J, Roger PP, Dumont JE: Phosphorylation of mitogen-activated protein kinases is involved in the epidermal growth factor and phorbol ester, but not in the thyrotropin/cAMP, thyroid mitogenic pathway. J Biol Chem 1993, 268:8398-840I.

72. Coulonval K, Vandeput F, Stein R, Kozma S, Lamy F, Dumont JE: Phosphatidylinositol 3-kinase, protein kinase $B$ and ribosomal S6 kinases in the stimulation of thyroid epithelial cell 
proliferation by cAMP and growth factors in the presence of insulin. Biochem J 2000, 348:35I-358.

73. Dumont JE, Maenhaut C, Christophe D, Vassart G, Roger PP: Thyroid regulatory factors. In Endocrinology Volume 94. Fifth Edition edition. Edited by: DeGroot LJ and Jameson JL. Elsevier Saunders; 2005:1837-1860.

74. Depoortere F, Dumont JE, Roger PP: Paradoxical accumulation of the cyclin-dependent kinase inhibitor p27kip I during the cAMP-dependent mitogenic stimulation of thyroid epithelial cells. J Cell Sci 1996, 109:1759-1764.

75. Kato JY, Matsuoka M, Polyak K, Massague J, Sherr CJ: Cyclic AMPinduced GI phase arrest mediated by an inhibitor (p27 Kip I) of cyclin-dependent kinase 4 activation. Cell 1994, 79:487-496.

76. L'Allemain G, Lavoie JN, Rivard N, Baldin V, Pouyssegur J: Cyclin D I expression is a major target of the cAMP-induced inhibition of cell cycle entry in fibroblasts. Oncogene 1997, 14:198|-1990.

77. Kato JY, Matsuoka M, Strom DK, Sherr C): Regulation of cyclin Ddependent kinase 4 (cdk4) by cdk4-activating kinase. Mol Cell Biol 1994, | 4:27|3-272|

78. Matsushime H, Quelle DE, Shurtleff SA, Shibuya M, Sherr CJ, Kato JY: D-type cyclin-dependent kinase activity in mammalian cells. Mol Cell Biol 1994, 14:2066-2076.

79. Cheng M, Sexl V, Sherr CJ, Roussel MF: Assembly of cyclin Ddependent kinase and titration of $\mathrm{p} 27 \mathrm{Kipl}$ regulated by mitogen-activated protein kinase kinase (MEKI). Proc Natl Acad Sci U S A 1998, 95:1091-1096.

80. Ladha MH, Lee KY, Upton TM, Reed MF, Ewen ME: Regulation of exit from quiescence by $\mathrm{p} 27$ and cyclin DI-CDK4. Mol Cell Biol 1998, I 8:6605-66/5.

8I. Dong F, Agrawal D, Bagui T, Pledger WJ: Cyclin D3-associated kinase activity is regulated by $\mathrm{p} 27 \mathrm{kip} /$ in BALB/c 3T3 cells. Mol Biol Cell 1998, 9:208I-2092.

82. Bockstaele L, Kooken H, Libert F, Paternot S, Dumont JE, de Launoit Y, Roger PP, Coulonval K: Regulated activating Thrl72 phosphorylation of cyclin-dependent kinase 4(CDK4): its relationship with cyclins and CDK "inhibitors". Mol Cell Biol 2006, 26:5070-5085.

83. Van Keymeulen A, Bartek J, Dumont JE, Roger PP: Cyclin D3 accumulation and activity integrate and rank the comitogenic pathways of thyrotropin and insulin in thyrocytes in primary culture. Oncogene 1999, 18:735I-7359.

84. Van Keymeulen A, Deleu S, Bartek J, Dumont JE, Roger PP: Respective roles of carbamylcholine and cyclic AMP in their synergistic regulation of cell cycle in thyroid primary cultures. Endocrinology 200I, 142:125I-1259.

85. Depoortere F, Pirson I, Bartek J, Dumont JE, Roger PP: Transforming growth factor beta(I) selectively inhibits the cyclic AMP. dependent proliferation of primary thyroid epithelial cells by preventing the association of cyclin D3-cdk4 with nuclear p27(kip I). Mol Biol Cell 2000, I I:I06I-1076.

86. Tanguay D, Pavlovic S, Piatelli MJ, Bartek J, Chiles TC: B cell antigen receptor-mediated activation of cyclin-dependent retinoblastoma protein kinases and inhibition by co-cross-linking with Fc gamma receptors. J Immunol 1999, 163:3160-3168.

87. Yang P, Roy SK: Follicle stimulating hormone-induced DNA synthesis in the granulosa cells of hamster preantral follicles involves activation of cyclin-dependent kinase- 4 rather than cyclin d2 synthesis. Biol Reprod 2004, 70:509-5I7.

88. Soos TJ, Kiyokawa H, Yan JS, Rubin MS, Giordano A, DeBlasio A, Bottega S, Wong B, Mendelsohn J, Koff A: Formation of p27-CDK complexes during the human mitotic cell cycle. Cell Growth Differ 1996, 7:135-I46.

89. Blain SW, Montalvo E, Massague J: Differential interaction of the cyclin-dependent kinase (Cdk) inhibitor p27 Kip I with cyclin A-Cdk2 and cyclin D2-Cdk4. J Biol Chem 1997, 272:25863-25872.

90. LaBaer J, Garrett MD, Stevenson LF, Slingerland JM, Sandhu C, Chou HS, Fattaey A, Harlow E: New functional activities for the p2 I family of CDK inhibitors. Genes Dev 1997, I I:847-862.

91. Coulonval K, Bockstaele L, Paternot S, Dumont JE, Roger PP: The cyclin D3-CDK4-p27kip I holoenzyme in thyroid epithelial cells: activation by TSH, inhibition by TGFbeta, and phosphorylations of its subunits demonstrated by two-dimensional gel electrophoresis. Exp Cell Res 2003, 29 I:I35-I49.

92. Cheng M, Olivier P, Diehl JA, Fero M, Roussel MF, Roberts JM, Sherr C): The p2I(Cip I) and p27(Kip I) CDK 'inhibitors' are essen- tial activators of cyclin D-dependent kinases in murine fibroblasts. $E M B O \mathrm{~J} 1999,18: 157 \mid-1583$

93. Bagui TK, Jackson RJ, Agrawal D, Pledger WJ: Analysis of cyclin D3cdk4 complexes in fibroblasts expressing and lacking p27(kip I) and p2 I (cip I). Mol Cell Biol 2000, 20:8748-8757.

94. Sugimoto M, Martin N, Wilks DP, Tamai K, Huot T], Pantoja C, Okumura K, Serrano M, Hara E: Activation of cyclin DI-kinase in murine fibroblasts lacking both p2I(CipI) and p27(Kipl). Oncogene 2002, $21: 8067-8074$.

95. Bagui TK, Mohapatra S, Haura E, Pledger WJ: P27KipI and p2 I Cipl are not required for the formation of active $D$ cyclin-cdk4 complexes. Mol Cell Biol 2003, 23:7285-7290.

96. Li Y, Jenkins $\mathrm{CW}$, Nichols MA, Xiong Y: Cell cycle expression and p53 regulation of the cyclin-dependent kinase inhibitor p2 I. Oncogene 1994, 9:226I-2268.

97. Kivinen L, Laiho M: Ras- and mitogen-activated protein kinase kinase-dependent and -independent pathways in p2ICip I/ Wafl induction by fibroblast growth factor-2, plateletderived growth factor, and transforming growth factorbeta I. Cell Growth Differ 1999, 10:621-628.

98. Weiss $\mathrm{RH}$, Joo A, Randour C: $\mathbf{p} 2 \mathrm{I}$ (Wafl/Cipl) is an assembly factor required for platelet-derived growth factor-induced vascular smooth muscle cell proliferation. I Biol Chem 2000, 275: 10285-10290.

99. Chang F, McCubrey JA: P2 I(Cip I) induced by Raf is associated with increased Cdk4 activity in hematopoietic cells. Oncogene 200I, 20:4354-4364.

100. Paternot S, Dumont JE, Roger PP: Differential utilization of cyclin DI and cyclin D3 in the distinct mitogenic stimulations of human thyrocytes by growth factors and TSH. Mol Endocrinol 2006, 20:in press.

I0I. Noseda M, Chang L, McLean G, Grim JE, Clurman BE, Smith LL, Karsan A: Notch activation induces endothelial cell cycle arrest and participates in contact inhibition: role of p2 ICip I repression. Mol Cell Biol 2004, 24:88I3-8822.

102. Dupont J, Karas M, LeRoith D: The cyclin-dependent kinase inhibitor p2 ICIP/WAF is a positive regulator of insulin-like growth factor I-induced cell proliferation in MCF-7 human breast cancer cells. J Biol Chem 2003, 278:37256-37264.

103. Kavurma MM, Khachigian LM: SpI inhibits proliferation and induces apoptosis in vascular smooth muscle cells by repressing p2IWAFI/CipI transcription and cyclin DI. Cdk4-p2 IWAFI/CipI complex formation. J Biol Chem 2003, 278:32537-32543.

104. Gaben AM, Saucier C, Bedin M, Barbu V, Mester J: Rapamycin inhibits cdk4 activation, $\mathrm{p} 2 \mathrm{I}$ (WAFI/CIPI) expression and GI-phase progression in transformed mouse fibroblasts. Int Cancer 2004, 108:200-206.

105. McConnell BB, Gregory FJ, Stott FJ, Hara E, Peters G: Induced expression of pI6(INK4a) inhibits both. Mol Cell Biol 1999, 19:1981-1989.

106. Parry D, Mahony D, Wills K, Lees E: Cyclin D-CDK subunit arrangement is dependent on the availability of competing INK4 and p2 I class inhibitors. Mol Cell Biol 1999, 19: I775- I783.

107. Reynisdottir I, Massague J: The subcellular locations of pI5(Ink4b) and p27(Kip I) coordinate their inhibitory interactions with cdk4 and cdk2. Genes Dev 1997, I I:492-503.

108. Reynisdottir I, Polyak K, lavarone A, Massague J: Kip/Cip and Ink4 Cdk inhibitors cooperate to induce cell cycle arrest in response to TGF-beta. Genes Dev 1995, 9:1831-1845.

109. Sandhu C, Garbe J, Bhattacharya N, Daksis J, Pan CH, Yaswen P, Koh J, Slingerland JM, Stampfer MR: Transforming growth factor beta stabilizes p I 5INK4B protein, increases p I 5 INK4B-cdk4 complexes, and inhibits cyclin DI-cdk4 association in human mammary epithelial cells. Mol Cell Biol 1997, 17:2458-2467.

110. Han J, Tsukada Y, Hara E, Kitamura N, Tanaka T: Hepatocyte growth factor induces redistribution of $\mathrm{p} 2 \mathrm{I}(\mathrm{CIPI})$ and p27(KIPI) through ERK-dependent pI6(INK4a) up-regulation, leading to cell cycle arrest at GI in HepG2 hepatoma cells. J Biol Chem 2005, 280:3 I548-3I556.

III. Swarbrick A, Lee CS, Sutherland RL, Musgrove EA: Cooperation of p27(Kipl) and pl 8(INK4c) in progestin-mediated cell cycle arrest in T-47D breast cancer cells. Mol Cell Biol 2000, 20:258|-259।. 
1 12. Gump J, Stokoe D, McCormick F: Phosphorylation of p I6INK4A correlates with Cdk4 association. I Biol Chem 2003, 278:6619-6622.

113. Stepanova L, Leng X, Parker SB, Harper JW: Mammalian p50Cdc37 is a protein kinase-targeting subunit of $\mathrm{Hsp} 90$ that binds and stabilizes Cdk4. Genes Dev 1996, I0:149I-I502.

II4. Vaughan CK, Gohlke U, Sobott F, Good VM, Ali MM, Prodromou C, Robinson CV, Saibil HR, Pearl LH: Structure of an Hsp90-Cdc37Cdk4 complex. Mol Cell 2006, 23:697-707.

II5. Lamphere L, Fiore F, Xu X, Brizuela L, Keezer S, Sardet C, Draetta GF, Gyuris J: Interaction between Cdc37 and Cdk4 in human cells. Oncogene 1997, 14:1999-2004.

I16. Zhao Q, Boschelli F, Caplan AJ, Arndt KT: Identification of a conserved sequence motif that promotes Cdc37 and cyclin DI binding to Cdk4. J Biol Chem 2004, 279: 12560-I2564.

1 17. Diehl JA, Yang W, Rimerman RA, Xiao H, Emili A: Hsc70 regulates accumulation of cyclin DI and cyclin DI-dependent protein kinase. Mol Cell Biol 2003, 23:1764-1774.

1 18. Sugimoto M, Nakamura T, Ohtani N, Hampson L, Hampson IN, Shimamoto A, Furuichi Y, Okumura K, Niwa S, Taya Y, Hara E: Regulation of CDK4 activity by a novel CDK4-binding protein, p34(SEI-I). Genes Dev 1999, 13:3027-3033.

119. Hsu SI, Yang CM, Sim KG, Hentschel DM, O'Leary E, Bonventre JV: TRIP-Br: a novel family of PHD zinc finger- and bromodomain-interacting proteins that regulate the transcriptional activity of E2F-I/DP-I. EMBO / 200I, 20:2273-2285.

I20. Tang DJ, Hu L, Xie D, Wu QL, Fang Y, Zeng Y, Sham JS, Guan XY: Oncogenic transformation by SEI-I is associated with chromosomal instability. Cancer Res 2005, 65:6504-6508.

121. Sim KG, Cheong JK, Hsu SI: The TRIP-Br family of transcriptional regulators is essential for the execution of cyclin $E$ mediated cell cycle progression. Cell Cycle 2006, 5: I I II-I II5.

122. Higashitsuji H, Itoh K, Nagao T, Dawson S, Nonoguchi K, Kido T, Mayer RJ, Arii S, Fujita J: Reduced stability of retinoblastoma protein by gankyrin, an oncogenic ankyrin-repeat protein overexpressed in hepatomas. Nat Med 2000, 6:96-99.

123. Dawson S, Higashitsuji H, Wilkinson AJ, Fujita J, Mayer RJ: Gankyrin: a new oncoprotein and regulator of $\mathrm{pRb}$ and $\mathrm{p53}$. Trends Cell Biol 2006, 16:229-233.

124. Iwai A, Marusawa H, Kiuchi T, Higashitsuji H, Tanaka K, Fujita J, Chiba $\mathrm{T}$ : Role of a novel oncogenic protein, gankyrin, in hepatocyte proliferation. J Gastroenterol 2003, 38:75|-758.

125. Dawson S, Apcher S, Mee M, Higashitsuji H, Baker R, Uhle S, Dubiel W, Fujita J, Mayer RJ: Gankyrin is an ankyrin-repeat oncoprotein that interacts with CDK4 kinase and the S6 ATPase of the 26 S proteasome. J Biol Chem 2002, 277:10893-10902.

126. Li J, Tsai MD: Novel insights into the INK4-CDK4/6-Rb pathway: counter action of gankyrin against INK4 proteins regulates the CDK4-mediated phosphorylation of Rb. Biochemistry 2002, 4I:3977-3983.

127. Laman H, Funes JM, Ye H, Henderson S, Galinanes-Garcia L, Hara E, Knowles P, McDonald N, Boshoff C: Transforming activity of Fbxo7 is mediated specifically through regulation of cyclin D/ cdk6. $E M B O$ J 2005, 24:3 I04-3II6.

128. Diehl JA, Sherr CJ: A dominant-negative cyclin DI mutant prevents nuclear import of cyclin- dependent kinase 4 (CDK4) and its phosphorylation by CDK-activating kinase. Mol Cell Biol 1997, 17:7362-7374

129. Tamamori-Adachi M, Ito $H$, Sumrejkanchanakij P, Adachi S, Hiroe M, Shimizu M, Kawauchi J, Sunamori M, Marumo F, Kitajima S, Ikeda MA: Critical role of cyclin DI nuclear import in cardiomyocyte proliferation. Circ Res 2003, 92:e I2-el9.

130. Gladden $A B$, Diehl JA: Location, location, location: the role of cyclin DI nuclear localization in cancer. I Cell Biochem 2005, 96:906-913.

131. Jaumot M, Estanyol JM, Serratosa J, Agell N, Bachs O: Activation of cdk4 and cdk2 during rat liver regeneration is associated with intranuclear rearrangements of cyclin-cdk complexes. Hepatology 1999, 29:385-395.

132. Tong W, Pollard JW: Progesterone inhibits estrogen-induced cyclin DI and cdk4 nuclear translocation, cyclin E- and cyclin A-cdk2 kinase activation, and cell proliferation in uterine epithelial cells in mice. Mol Cell Biol I999, 19:225I-2264.

133. Alt JR, Cleveland JL, Hannink M, Diehl JA: Phosphorylationdependent regulation of cyclin DI nuclear export and cyclin
DI-dependent cellular transformation. Genes Dev 2000, |4:3|02-3||4.

134. Diehl JA, Sherr CJ: A dominant-negative cyclin DI mutant prevents nuclear import of cyclin- dependent kinase 4 (CDK4) and its phosphorylation by CDK- activating kinase. Mol Cell Biol 1997, 17:7362-7374.

135. Alt JR, Gladden AB, Diehl JA: p2 I(Cip I) Promotes cyclin DI nuclear accumulation via direct inhibition of nuclear export. J Biol Chem 2002, 277:85 17-8523.

136. Villalonga P, Rius E, Bachs O, Agell N: [Lys6I]N-Ras is able to induce full activation and nuclear accumulation of Cdk4 in NIH3T3 cells. Oncogene 2000, 19:690-699.

137. Naderi S, Gutzkow KB, Lahne HU, Lefdal S, Ryves WJ, Harwood AJ, Blomhoff HK: cAMP-induced degradation of cyclin D3 through association with GSK-3 beta\}. J Cell Sci 2004, I I7:3769-3783.

138. Taules M, Rius E, Talaya D, Lopez-Girona A, Bachs O, Agell N: Calmodulin is essential for cyclin-dependent kinase 4 (Cdk4) activity and nuclear accumulation of cyclin DI-Cdk4 during GI. J Biol Chem 1998, 273:33279-33286.

139. Taules M, Rodriguez-Vilarrupla A, Rius E, Estanyol JM, Casanovas O, Sacks DB, Perez-Paya E, Bachs O, Agell N: Calmodulin binds to p2I(Cipl) and is involved in the regulation of its nuclear localization. J Biol Chem 1999, 274:24445-24448.

140. Zhou BP, Liao Y, Xia W, Spohn B, Lee MH, Hung MC: Cytoplasmic localization of p2 I Cip I/WAFI by Akt-induced phosphorylation in HER-2/neu-overexpressing cells. Nat Cell Biol 200I, 3:245-252.

141. Rossig L, Jadidi AS, Urbich C, Badorff C, Zeiher AM, Dimmeler S: Akt-dependent phosphorylation of p2I(Cipl) regulates PCNA binding and proliferation of endothelial cells. Mol Cell Biol 200I, 2 I:5644-5657.

142. Li Y, Dowbenko D, Lasky LA: AKT/PKB phosphorylation of p2 I Cip/WAFI enhances protein stability of p2 ICip/WAF I and promotes cell survival. / Biol Chem 2002, 277: | |352-I I36|.

143. Wang Z, Bhattacharya N, Mixter PF, Wei W, Sedivy J, Magnuson NS: Phosphorylation of the cell cycle inhibitor 22 I Cip I/WAF I by Pim-I kinase. Biochim Biophys Acta 2002, I 593:45-55.

144. Ishida N, Kitagawa M, Hatakeyama S, Nakayama K: Phosphorylation at serine 10, a major phosphorylation site of p27(Kip I), increases its protein stability. I Biol Chem 2000, 275:25I46-25I54.

145. Ishida N, Hara T, Kamura T, Yoshida M, Nakayama K, Nakayama KI: Phosphorylation of p27Kipl on serine 10 is required for its binding to CRMI and nuclear export. J Biol Chem 2002, 277: $14355-14358$.

146. Rodier G, Montagnoli A, Di Marcotullio L, Coulombe P, Draetta GF, Pagano M, Meloche S: p27 cytoplasmic localization is regulated by phosphorylation on Ser 10 and is not a prerequisite for its proteolysis. EMBO J 200I, 20:6672-6682.

147. Boehm M, Yoshimoto T, Crook MF, Nallamshetty S, True A, Nabel G], Nabel EG: A growth factor-dependent nuclear kinase phosphorylates p27(KipI) and regulates cell cycle progression. EMBO / 2002, $21: 3390-3401$.

148. Viglietto G, Motti ML, Bruni P, Melillo RM, D'Alessio A, Califano D, Vinci F, Chiappetta G, Tsichlis P, Bellacosa A, Fusco A, Santoro M: Cytoplasmic relocalization and inhibition of the cyclindependent kinase inhibitor p27Kip I by PKB/Akt-mediated phosphorylation in breast cancer. Nat Med 2002, 8: I I36- I I 44.

149. Liang J, Zubovitz J, Petrocelli T, Kotchetkov R, Connor MK, Han K, Lee JH, Ciarallo S, Catzavelos C, Beniston R, Franssen E, Slingerland JM: PKB/Akt phosphorylates p27, impairs nuclear import of p27 and opposes p27-mediated GI arrest. Nat Med 2002, 8:1153-1160.

150. Shin I, Yakes FM, Rojo F, Shin NY, Bakin AV, Baselga J, Arteaga CL: PKB/Akt mediates cell-cycle progression by phosphorylation of p27Kip I at threonine 157 and modulation of its cellular localization. Nat Med 2002, 8:1।45-1 I52.

15I. Shin I, Rotty J, Wu FY, Arteaga CL: Phosphorylation of p27Kip I at Thr- 157 interferes with its association with importin alpha during GI and prevents nuclear re-entry. I Biol Chem 2005, 280:6055-6063.

152. Takahashi H, Menjo M, Kaneko Y, lkeda K, Matsushime H, Nakanishi M: Cdk4 activation is dependent on the subunit rearrangement in the complexes. Biochem Biophys Res Commun 2000, 267:388-393. 
153. Obaya AJ, Kotenko I, Cole MD, Sedivy JM: The proto-oncogene cmyc acts through the cyclin-dependent kinase (Cdk) inhibitor p27(KipI) to facilitate the activation of Cdk4/6 and early G(I) phase progression. J Biol Chem 2002, 277:3 I263-3/269.

154. Kato A, Takahashi $\mathrm{H}$, Takahashi $\mathrm{Y}$, Matsushime $\mathrm{H}$ : Inactivation of the cyclin D-dependent kinase in the rat fibroblast cell line, 3YI, induced by contact inhibition. I Biol Chem 1997, 272:8065-8070.

155. Stein GH, Drullinger LF, Soulard A, Dulic V: Differential roles for cyclin-dependent kinase inhibitors p2I and pl6 in the mechanisms of senescence and differentiation in human fibroblasts. Mol Cell Biol 1999, 19:2109-2II7.

156. Skildum AJ, Mukherjee S, Conrad SE: The cyclin-dependent kinase inhibitor $\mathrm{P} 2 \mathrm{IWAFI/Cip} \mathrm{I} \mathrm{is} \mathrm{an} \mathrm{antiestrogen-regulated}$ inhibitor of Cdk4 in human breast cancer cells. J Biol Chem 2002, 277:5I45-5I52.

157. Kahl CR, Means AR: Regulation of cyclin DI/Cdk4 complexes by calcium/calmodulin-dependent protein kinase I. J Biol Chem 2004, 279: $15411-15419$.

158. Roger PP, Demartin S, Dumont JE: Nature of the critical labile event that controls RB phosphorylation in the cyclic AMPdependent cell cycle of thyrocytes in primary culture. Exp Cell Res 1999, 252:492-498.

159. Paternot S, Coulonval K, Dumont JE, Roger PP: Cyclic AMPdependent phosphorylation of cyclin D3-bound CDK4 determines the passage through the cell cycle restriction point in thyroid epithelial cells. J Biol Chem 2003, 278:26533-26540.

160. Fortemaison N, Blancquaert S, Dumont JE, Maenhaut C, Aktories K, Roger PP, Dremier S: Differential involvement of the actin cytoskeleton in differentiation and mitogenesis of thyroid cells: inactivation of Rho proteins contributes to cyclic adenosine monophosphate-dependent gene expression but prevents mitogenesis. Endocrinology 2005, I 46:5485-5495.

161. Olashaw N, Bagui TK, Pledger WJ: Cell cycle control: a complex issue. Cell Cycle 2004, 3:263-264.

162. Sherr CJ, Roberts JM: CDK inhibitors: positive and negative regulators of GI-phase progression. Genes Dev 1999, 13:1501-1512.

163. Zhang $H$, Hannon GJ, Beach D: p2I-containing cyclin kinases exist in both active and inactive states. Genes Dev 1994, 8: $1750-1758$.

164. Russo AA, Jeffrey PD, Patten AK, Massague J, Pavletich NP: Crystal structure of the p27Kip I cyclin-dependent-kinase inhibitor bound to the cyclin A-Cdk2 complex. Nature 1996, 382:325-331.

165. Hengst L, Gopfert U, Lashuel HA, Reed SI: Complete inhibition of Cdk/cyclin by one molecule of p2 I(CipI). Genes Dev 1998, I 2:3882-3888.

166. Lacy ER, Filippov I, Lewis WS, Otieno S, Xiao L, Weiss S, Hengst L, Kriwacki RW: p27 binds cyclin-CDK complexes through a sequential mechanism involving binding-induced protein folding. Nat Struct Mol Biol 2004, I I:358-364.

167. Muraoka RS, Lenferink AE, Simpson J, Brantley DM, Roebuck LR, Yakes FM, Arteaga CL: Cyclin-dependent kinase inhibitor p27(Kipl) is required for mouse mammary gland morphogenesis and function. J Cell Biol 200I, I53:917-932.

168. Muraoka RS, Lenferink AE, Law B, Hamilton E, Brantley DM, Roebuck LR, Arteaga CL: ErbB2/Neu-induced, cyclin DI-dependent transformation is accelerated in p27-haploinsufficient mammary epithelial cells but impaired in p27-null cells. Mol Cell Biol 2002, 22:2204-2219.

169. Gao H, Ouyang X, Banach-Petrosky W, Borowsky AD, Lin Y, Kim M, Lee H, Shih WJ, Cardiff RD, Shen MM, Abate-Shen C: A critical role for p27kipl gene dosage in a mouse model of prostate carcinogenesis. Proc Natl Acad Sci U S A 2004, I 0 I: 17204- 17209.

170. Terada $\mathrm{Y}$, Tatsuka M, Jinno S, Okayama H: Requirement for tyrosine phosphorylation of Cdk4 in GI arrest induced by ultraviolet irradiation. Nature 1995, 376:358-362.

171. Jinno S, Hung SC, Okayama H: Cell cycle start from quiescence controlled by tyrosine phosphorylation of cdk4. Oncogene 1999, 18:565-57।.

172. lavarone A, Massague J: Repression of the CDK activator Cdc25A and cell-cycle arrest by cytokine TGF-beta in cells lacking the CDK inhibitor p I5. Nature 1997, 387:417-422.

173. Sexl V, Diehl JA, Sherr CJ, Ashmun R, Beach D, Roussel MF: A rate limiting function of cdc25A for $\mathbf{S}$ phase entry inversely corre- lates with tyrosine dephosphorylation of Cdk2. Oncogene 1999, 18:573-582.

174. Watanabe N, Broome M, Hunter T: Regulation of the human WEEIHu CDK tyrosine I5-kinase during the cell cycle. EMBO J 1995, 14:1878-189|.

175. Matsuoka M, Kato JY, Fisher RP, Morgan DO, Sherr C]: Activation of cyclin-dependent kinase 4 (cdk4) by mouse MOI5-associated kinase. Mol Cell Biol 1994, 14:7265-7275.

176. Tassan JP, Schultz SJ, Bartek J, Nigg EA: Cell cycle analysis of the activity, subcellular localization, and subunit composition of human CAK (CDK-activating kinase). J Cell Biol 1994, I 27:467-478.

177. Darbon JM, Devault A, Taviaux S, Fesquet D, Martinez AM, Galas S, Cavadore JC, Doree M, Blanchard JM: Cloning, expression and subcellular localization of the human homolog of $\mathrm{p} 40 \mathrm{MO} / 5$ catalytic subunit of cdk-activating kinase. Oncogene 1994, 9:3127-3138.

178. Polyak K, Kato JY, Solomon MJ, Sherr CJ, Massague J, Roberts JM, Koff A: p27Kip I, a cyclin-Cdk inhibitor, links transforming growth factor-beta and contact inhibition to cell cycle arrest. Genes Dev 1994, 8:9-22.

179. Aprelikova O, Xiong Y, Liu ET: Both p16 and p2 I families of cyclin-dependent kinase (CDK) inhibitors block the phosphorylation of cyclin-dependent kinases by the CDK-activating kinase. J Biol Chem 1995, 270:18195-18197.

180. Kaldis P, Russo AA, Chou HS, Pavletich NP, Solomon MJ: Human and yeast cdk-activating kinases (CAKs) display distinct substrate specificities. Mol Biol Cell 1998, 9:2545-2560.

181. Fisher RP: Secrets of a double agent: CDK7 in cell-cycle control and transcription. J Cell Sci 2005, I I 8:5 I7I-5I80.

182. Coulonval K, Bockstaele L, Paternot S, Roger PP: Phosphorylations of cyclin-dependent kinase 2 revisited using two-dimensional gel electrophoresis. J Biol Chem 2003, 278:52052-52060.

183. Harper JW, Elledge SJ: The role of Cdk7 in CAK function, a retro-retrospective. Genes Dev 1998, I 2:285-289.

184. Kaldis P: The cdk-activating kinase (CAK): from yeast to mammals. Cell Mol Life Sci 1999, 55:284-296.

185. Nagahara H, Ezhevsky SA, Vocero-Akbani AM, Kaldis P, Solomon MJ, Dowdy SF: Transforming growth factor beta targeted inactivation of cyclin E:cyclin-dependent kinase 2 (Cdk2) complexes by inhibition of Cdk2 activating kinase activity. Proc Natl Acad Sci U S A 1999, 96: | 496 I-14966.

186. Chiariello M, Gomez E, Gutkind JS: Regulation of cyclin-dependent kinase (Cdk) 2 Thr- 160 phosphorylation and activity by mitogen-activated protein kinase in late GI phase. Biochem J 2000, 349:869-876.

187. Lents NH, Keenan SM, Bellone C, Baldassare J]: Stimulation of the Raf/MEK/ERK cascade is necessary and sufficient for activation and Thr- 160 phosphorylation of a nuclear-targeted CDK2. J Biol Chem 2002, 277:47469-47475.

188. Ukomadu C, Dutta A: Inhibition of cdk2 Activating Phosphorylation by Mevastatin. J Biol Chem 2003, 278:4840-4846.

189. Larochelle S, Pandur J, Fisher RP, Salz HK, Suter B: Cdk7 is essential for mitosis and for in vivo Cdk-activating kinase activity. Genes Dev 1998, I 2:370-38I.

190. Kaldis P, Pitluk ZW, Bany IA, Enke DA, Wagner M, Winter E, Solomon MJ: Localization and regulation of the cdk-activating kinase (Cak I p) from budding yeast. I Cell Sci 1998, I I I ( Pt 24):3585-3596.

191. Shimotohno A, Umeda-Hara C, Bisova K, Uchimiya H, Umeda M: The plant-specific kinase CDKF; I is involved in activating phosphorylation of cyclin-dependent kinase-activating kinases in Arabidopsis. Plant Cell 2004, 16:2954-2966.

192. Shimotohno A, Ohno R, Bisova K, Sakaguchi N, Huang J, Koncz C, Uchimiya $H$, Umeda $M$ : Diverse phosphoregulatory mechanisms controlling cyclin-dependent kinase-activating kinases in Arabidopsis. Plant J 2006, 47:70 I-710.

193. Kaldis P, Solomon MJ: Analysis of CAK activities from human cells. Eur J Biochem 2000, 267:42। 3-4221.

194. Liu Y, Wu C, Galaktionov K: p42, a novel cyclin-dependent kinase-activating kinase in mammalian cells. J Biol Chem 2004, 279:4507-45।4.

195. Wohlbold L, Larochelle S, Liao JC, Livshits G, Singer J, Shokat KM, Fisher RP: The cyclin-dependent kinase (CDK) family member PNQALRE/CCRK supports cell proliferation but has no 
intrinsic CDK-activating kinase (CAK) activity. Cell Cycle 2006, 5:546-554

196. Faast R, White J, Cartwright P, Crocker L, Sarcevic B, Dalton S: Cdk6-cyclin D3 activity in murine ES cells is resistant to inhibition by p I 6(INK4a). Oncogene 2004, 23:49I-502.

197. Lin J, Jinno S, Okayama H: Cdk6-cyclin D3 complex evades inhibition by inhibitor proteins and uniquely controls cell's proliferation competence. Oncogene 2001, 20:2000-2009.

198. Lee YM, Sicinski P: Targeting cyclins and cyclin-dependent kinases in cancer: lessons from mice, hopes for therapeutic applications in human. Cell Cycle 2006, 5:21 I0-2114.

199. Sweeney KJ, Swarbrick A, Sutherland RL, Musgrove EA: Lack of relationship between CDK activity and $G$ I cyclin expression in breast cancer cells. Oncogene 1998, 16:2865-2878.

Publish with Bio Med Central and every scientist can read your work free of charge

"BioMed Central will be the most significant development for disseminating the results of biomedical research in our lifetime. "

Sir Paul Nurse, Cancer Research UK

Your research papers will be:

- available free of charge to the entire biomedical community

- peer reviewed and published immediately upon acceptance

- cited in PubMed and archived on PubMed Central

- yours - you keep the copyright

Submit your manuscript here:

http://www.biomedcentral.com/info/publishing_adv.asp
BiolMedcentral 